\title{
Sağlık Mesleği Mensuplarının Suçu Bildirmemesi Suçu (TCK m 280)
}

\author{
Levent Emre Özgüç̧* (1)
}

Öz

Bu çalışmada, 5237 sayılı Türk Ceza Kanunu'nun 280. maddesinde düzenlenen "Sağlık Mesleği Mensuplarının Suçu Bildirmemesi" suçu ele alınmaktadır. Suç kanunun ikinci kitabının "Millete ve Devlete Karşı Suçlar" başlıklı dördüncü kısmının "Adliyeye Karşı Suçlar" başıklı ikinci bölümünde yer almaktadır ve 765 sayılı mülga Türk Ceza Kanunu’nun "Cürmü Haber Vermekte Zühul" başııkı 530. maddesinin karşılığıdır. 5237 sayılı TCK m 280 uyarınca, görevi sırasında belirtisiyle karşılaştğı bir suçu yetkili makamlara bildirmeyen veya bildirimde gecikme gösteren sağlık mesleği mensubu hapis cezasıyla cezalandırılmaktadır. Suç tanımında bildirim yükümlülüğünün doğmasına neden olacak suçlara ilişkin herhangi bir sınırlama yapılmamış olması sağlık mesleği mensuplarının oldukça geniş bir yükümlülükle karşı karşıya kalmasına sebep olmuştur. Suçun incelenmesi sırasında düzenlemeye ilişkin tartş̧malar hakkında bilgi verilmiştir. Bu kapsamda suçla korunan hukuki değerin ne olduğu, failin sahip olması gereken sağlık mesleği mensubu kavramının kimleri kapsadığı, aynı zamanda kamu görevlisi olan sağlık mesleği mensuplarının suç bakımından durumları, suç işlendiğini gösteren belirti kavramının anlamı, belge ve beyanların bu kapsamda olup olmayacağı, suçun olası kastla işlenip işlenemeyeceği, sağlık mesleği mensubunun sır saklama yükümlülüğü, tanıklıktan çekinme hakkı veya tedavi yükümlülüğünün suçta hukuka aykırıı̆ı kaldıran neden sayııр sayılmayacağı, TCK $\mathrm{m} 280$ ile benzer yükümlülükleri düzenleyen suçlar arasındaki içtima ilişkisi gibi hususlar çözülmeye çalışılmıştr.

Anahtar Kelimeler
Sağlık mesleği mensubu, Suçu bildirme yükümlülüğü, Adliyeye karşı suçlar, Sır saklama yükümlülüğü, Tanıkıktan çekinme hakkı

The Crime of Failure by Medical Professionals to Report an Offence (TCC Art. 280)

\begin{abstract}
The topic of analysis of this paper is the crime of "Failure by Medical Professionals to Report an Offence", found in article 280 of the Turkish Criminal Code numbered 5237. The crime is situated in the second part, titled "Crimes against the Judiciary", under the fourth section, titled "Crimes against the Nation and the State", under the second book of the Code, and is the equivalent of Article 530 of the annulled Turkish Criminal Code numbered 765. Pursuant to Art. 280, medical professionals who encounter an indication pointing towards a crime in the course of their duties, and do not notify the authorities of that fact or show delay in their notifications, are punishable by imprisonment. The lack of any limitation concerning the encountered crime which would create the obligation to report caused the medical professionals to face an obligation of substantial extent. Throughout the analysis of the crime, the doctrinal discussions concerning the crime are evaluated. In this context, the topics such as the norm's protected legal value, the scope of the term medical professional, the status of medical professionals in the public sector, the definition of the term indication in relation to the crime and whether documents and statements are included, whether the crime is committable by probable intent, whether the patient-doctor privilege, the right to be excused from testifying or the obligation to give treatment are justifications for the crime, and the rules of aggregation between TCC Art. 280 and similar crimes are explained.
\end{abstract}

\section{Keywords}

Medical professional, Obligation to report an offence, Crimes against the judiciary, Patient-doctor privilege, Right to be excused from testifying

Sorumlu Yazar: Levent Emre Özgüç (Arş. Gör.), Koç Üniversitesi, Hukuk Fakültesi, Ceza ve Ceza Muhakemesi Hukuku Ana Bilim Dalı, İstanbul, Türkiye. E-posta: lozguc@ku.edu.tr ORCID: 0000-0002-4561-1601

Atff: Ozguc LE, “Sağlık Mesleği Mensuplarının Suçu Bildirmemesi Suçu (TCK m 280)" (2019) 77(2) i̇stanbul Hukuk Mecmuası 999. https://doi.org/10.26650/mecmua.2019.77.2.0016 


\section{Extended Summary}

In this paper, the crime of "Failure by Medical Professionals to Report an Offence" in Article 280 of the Turkish Criminal Code numbered 5237, is evaluated through the examination of its protected legal value, its objective and subjective elements, the legal justifications and excuses applicable to the crime, the issues of attempt, aggregation, participation and the adjudication procedure of the crime.

The crime aims to protect the effectiveness of judicial functions, with the purposes of providing an effective investigation of crimes, realizing the purposes of criminal law, and protecting public order.

Pursuant to Art. 280, only a person who is a medical professional may commit the crime. The definition of the term "medical professional" is to be solved in light of the relevant legislation, especially the Codes numbered 657 and 1219. This paper argues that medical professionals in both public and private sectors may be perpetrators, even though the prevailing opinion is that only medical professionals who are not public officials may commit Art. 280.

There are no limitations as to which types of offences the medical professionals must encounter for the obligation to report to be born, except the case of effective remorse in the crime found in Article 191. The patient of the medical professional may be the perpetrator, the victim or a mere witness. However, the encountered offence must constitute a crime, therefore misdemeanors or torts do not create the obligation to report.

The medical professional must encounter an indication pointing towards the commission of an offence. The term "indication" used in the original letter of the law points towards material evidence, which caused the Turkish literature on the crime to argue that only encountering material and circumstantial evidence would cause the obligation to report, but statements or documents pointing to the offence do not. However, this paper is in the view that such a distinction was not the aim of the legislator and would lead to erroneous consequences. After encountering an indication in the course of duty as a medical professional, the failure to notify or delay in doing so constitutes the crime in Article 280. The meaning of authorities shall be interpreted in accordance with Art. 158 of the Criminal Procedure Code. There is a delay when significant obstacles in the investigation occur because of the failure to report.

The crime may be committed with direct or probable intent. In any case, the intent must extend to all objective elements of the crime.

The right to be silent may be exercised with regards to crimes committed by individuals covered by the right. However, in light of Art. 23 of the Regulation on 
Patient Rights, the patient-doctor privilege may not be asserted when a legal obligation in conflict exists. While medical doctors are required to report the indication they have encountered, they may be excused from testifying pursuant to Art. 46 of the Criminal Procedure Code. Lastly, the will of the individual from whom the crime is learnt is insignificant, even when that individual is the victim and the investigation of the crime is bound to legal complaint.

Rules of attempt may not be applied to Art. 280 because of the crime's nature. Additionally, the crime may only be perpetrated by medical professionals, but other individuals who do not hold this title may participate in the commission of the crime by aiding to or instigating the commission. A discussion exists whether Arts. 278, 279 and 280 have the relationship of general and specific norms. The view presented in this paper is that Art. 278 is a general norm to both 279 and 280, but such a relationship may not be established between the latter two. The issue of aggregation of these two types of crimes is to be solved through the application of the rules of conceptual aggregation. Other possible crimes to be aggregated with Art. 280 are Art. 257 (misconduct of duty by a public official), Art. 252 (bribery) and Art. 210 (falsification of an official document).

The punishment prescribed in Art. 280 is imprisonment to one year. As this is a short-term prison sentence, it may be converted to alternative sanctions pursuant to Art. 50 of the TCC. Additionally, the announcement of the sentence may be deferred in line with the rules provided in Art. 231 of the Criminal Procedure Code, or the execution of the sentence may be deferred pursuant to Art. 51 of the TCC. 


\section{Sağlık Mesleği Mensuplarının Suçu Bildirmemesi Suçu (TCK m 280)}

\section{Genel Olarak}

Sağlık mesleği mensuplarının suçu bildirmemesi suçu 5237 sayılı Türk Ceza Kanunu'nun (TCK) "Özel Hükümler" başlıklı ikinci kitabının "Millete ve Devlete Karşı Suçlar" başlıklı dördüncü kısmının "Adliyeye Karşı Suçlar" başlıklı ikinci bölümünde, 280. maddede şu şekilde düzenlenmiştir:

\section{Săğlk mesleği mensuplarının suçu bildirmemesi}

(1) Görevini yaptığı sırada bir suçun işlendiği yönünde bir belirti ile karşılaşmasına rağmen, durumu yetkili makamlara bildirmeyen veya bu hususta gecikme gösteren sağllk mesleği mensubu, bir yıla kadar hapis cezası ile cezalandirılır.

(2) Să̆llk mesleği mensubu deyiminden tabip, diş tabibi, eczacl, ebe, hemşire ve sağllk hizmeti veren diğer kişiler anlaşılır.

Madde, önceki 765 sayılı TCK'nın 530'uncu maddesinde yer alan “Cürmü haber vermekte zühul" suçunun ${ }^{2}$ karşıllğıdır, ancak iki düzenleme arasında kapsam ve ceza bakımından ciddi farklar olduğunu belirtmek gerekir. 765 sayılı Türk Ceza Kanunu'nda fiil karşıllğında yalnızca para cezasının öngörüldüğü bir kabahat olarak düzenlenmişken, 5237 sayılı Türk Ceza Kanunu'nda bu kabahat bir suça dönüştürülmüş, kapsamı genişletilmiş ve suç karşıllığında öngörülen ceza hapis cezası haline gelmiştir.

Bunun yanında, TCK m 280 ile düzenlenen sağlık meslek mensuplarının suçu bildirmemesi suçu, TCK m $278^{\prime} \mathrm{de}^{3}$ ve m $279^{\prime} \mathrm{da}^{4}$ yer alan ve sırasıyla genel suçu bildirme yükümlülüğünün ve kamu görevlilerinin suçu bildirme yükümlülüğünün ihlalinin sonuçlarını düzenleyen kurallarla da bağlantılıdır; ancak TCK m 280'de düzenlenen hükmün diğer iki maddeden belirli farklarının da olduğu ifade edilmelidir ${ }^{5}$.

5237 sayılı ve 26.09.2004 tarihli Türk Ceza Kanunu. Kanun 25611 sayılı ve 12.10.2004 tarihli Resmi Gazete'de yayımının ardından 01.06.2005 tarihinde yürürlüğe girmiştir.

2 Söz konusu 530. madde şu şekildedir: "Hekim, cerrah, ebe yahut sair sıhhıe memurları şahıslar aleyhinde işlenmiş bir cürüm asarını gösteren ahvalde sanatlarının icabettiği yardımı ifa ettikten sonra keyfiyeti adliyeye veya zabıtaya bildirmezler yahut ihbar hususunda teahhur gösterirlerse bu ihbar kendisine yardım ettikleri kimseyi takibata maruz kılacak ahval müstesna olmak üzere otuz liraya kadar hafif cezayı nakdiye mahkum olurlar.”

3 "Suçu bildirmeme" başlıklı 5237 sayılı TCK m 278: "(1) İşlenmekte olan bir suçu yetkili makamlara bildirmeyen kişi, bir yıla kadar hapis cezası ile cezalandırılır. (2) İşlenmiş olmakla birlikte, sebebiyet verdiği neticelerin sınırlandırılması halen mümkün bulunan bir suçu yetkili makamlara bildirmeyen kişi, yukarıdaki fikra hükmüne göre cezalandırılır. (3) Mağdurun on beş yaşını bitirmemiş bir çocuk, bedensel veya ruhsal bakımdan engelli olan ya da hamileliği nedeniyle kendisini savunamayacak durumda bulunan kimse olması halinde, yukarıdaki fikralara göre verilecek ceza, yarı oranında artırılır. (4) Tanıklıktan çekinebilecek olan kişiler bakımından cezaya hükmolunmaz. Ancak, suçu önleme yükümlülüğünün varlığı dolayısıyla ceza sorumluluğuna ilişkin hükümler saklıdır."

4 "Kamu görevlisinin suçu bildirmemesi” başlıklı 5237 sayılı TCK m 279: “(1) Kamu adına soruşturma ve kovuşturmayı gerektiren bir suçun işlendiğini göreviyle bağlantılı olarak öğrenip de yetkili makamlara bildirimde bulunmayı ihmal eden veya bu hususta gecikme gösteren kamu görevlisi, altı aydan iki yıla kadar hapis cezası ile cezalandırılır. (2) Suçun, adlî kolluk görevini yapan kişi tarafından işlenmesi halinde, yukarıdaki fikraya göre verilecek ceza yarı oranında artırılır."

5 Bu farklar suçun unsurlarına ve özel görünüm biçimlerine ilişkin kısımlarda incelenmektedir. 
Bu eserde, TCK m 280'de yer alan suç; suçun koruduğu hukuksal değer, unsurlar1, suç bakımından hukuka aykırılığı ve kusurluluğu kaldıran nedenler, suçun özel görünüm biçimleri ile yaptırım ve kovuşturma usulü üzerinde durulmak suretiyle incelenecektir.

\section{Suçla Korunan Hukuksal Değer}

TCK m 280 ile korunan hukuksal değerin ne olduğu konusunda doktrinde çeşitli görüşler ileri sürülmüştür. Çeşitli görüşler; suçun, "Adliyeye Karş1 Suçlar” başlığ1 altında düzenlenmiş olmasından hareketle, adliyeyi ${ }^{6}$, adli makamların işbirliğini ${ }^{7}$, adliyenin fonksiyon ve faaliyetlerini ${ }^{8}$ veya bu fonksiyonların yerine getirilmesi ile suçların takibindeki toplumsal menfaati ${ }^{9}$ koruduğunu ileri sürmektedir. Bir kısım yazar ise suçun adliyeyi koruyan bir düzenleme olduğunu kabul etmekle birlikte, adliyenin yanında bildirim yükümlülüğüne konu olan suçla korunan değerin de muhafaza altına alındığını belirtmiştir ${ }^{10}$. Alman ceza hukukunda da, benzer bir düzenlemeyi içeren Alman Ceza Kanunu ("Alman CK”) m 138 ile, suçların önlenmesi aracı olarak adliyenin ve bildirim konusu suçla korunan hukuksal değerin korunduğu ifade edilmektedir ${ }^{11}$. Ancak Alman CK'daki ilgili hüküm TCK m 280'den yalnızca önlenebilecek suçların bildirimini öngörmesiyle ayrılmaktadır. $\mathrm{Bu}$ açıdan suçun TCK m 280'den çok m 278'e benzer olduğu söylenebilir. Türk öğretisinde ayrıca öne sürülen bir diğer görüşe göre suçla korunan değerin adliye olmasına imkan yoktur, zira adil yargılanma hakkından bağımsız böyle bir hukuksal değer yoktur, bu sebeple suçla korunan değer adliye değil, bireylerin adil yargılanma hakkıdır ${ }^{12}$.

\footnotetext{
Durmuş Tezcan, Mustafa Ruhan Erdem and R Murat Önok, Teorik ve Pratik Ceza Özel Hukuku (16th edn, Seçkin Yayıncılık 2018) 1255; Özlem Yenerer Çakmut, 'Sağlık Mesleği Mensuplarının Suçu Bildirmemesi Suçu (TCK m 280)' (2006) 12 Marmara Üniversitesi Hukuk Fakültesi Hukuk Araştırmaları Dergisi 1051, 1051; Umut Emre Yağlıdere, 'Sağlık Mesleği Mensuplarının Suçu Bildirmemesi Suçu’ (2018) 6 Kadir Has Üniversitesi Hukuk Fakültesi Dergisi 59, 62; Pınar Bulut, 'Sağlı Mesleği Mensuplarının Suçu Bildirmemesi', Să̆llk Hukuku Makaleleri (İstanbul Barosu Yayınları 2012) 84; Özkan Gültekin, 'Sağlık Mesleği Mensuplarının Suçu Bildirmemesi' (2016) 11 Terazi Hukuk Dergisi 103, 106; Hüriye Elif İplikçi, 'Türk Ceza Hukukunda Suçu Bildirmeme Suçları' (Ankara Üniversitesi 2010) 82; Çetin Arslan and Bahattin Azizağaoğlu, Yeni Türk Ceza Kanunu Şerhi (Asil Yayın Dağıtım 2004) 1123; Hakan Hakeri, Tıp Hukuku (16th edn, Seçkin Yayıncılık 2019) 1272.

7 Hamide Zafer, 'Sağlık Mesleği Mensuplarının Suçu Bildirmemesi Suçu (TCK m 280)' (2013) 71 İstanbul Üniversitesi Hukuk Fakültesi Mecmuası 1327, 1334.

8 Mehmet Öget, 'Sağlık Mesleği Mensuplarının Suçu Bildirmemesi (TCK 280)' [2015] Leges İzmir Üniversitesi Sağlık Hukuku Dergisi 53, 63.

9 İlhan Üzülmez, 'Sağlık Mesleği Mensuplarının Suçu Bildirmemesi Suçu', Tip Ceza Hukukunun Güncel Sorunları (Türkiye Barolar Birliği 2008) 827; Mahmut Koca and İlhan Üzülmez, Türk Ceza Hukuku Özel Hükümler (4th edn, Seçkin Yayınc1lık 2017) 944.

10 Tezcan, Erdem and Önok (n 7) 1245-1246; Mustafa Ruhan Erdem, 'Suçu Bildirmeme Suçu (TCK m 278)' [2009] Türkiye Barolar Birliği Dergisi 105, 106. Ancak yazarların bu yorumlarını TCK m 278'de yer alan ve faili özgü olmayan "Suçu Bildirmeme" suçuna ilişkin olarak yaptıklarına dikkat çekilmelidir.

11 Adolf Schönke and Horst Schröder, Strafgesetzbuch Kommentar (28th edn, Verlag CH Beck 2010) 1451; Thomas Fischer, Beck'sche Kurz Kommentare - Strafgesetzbuch Und Nebengesetzen (57th edn, Verlag CH Beck 2009) 962.

12 Yener Ünver, 'TCK'da Sağlık Personelinin Ceza Hukuku Sorumluluğuna Yol Açabilecek Hükümler', Uluslararası II. Sağlık Hukuku Sempozyumu (On İki Levha Yayıncılık 2011) 103; Yener Ünver, TCK’da Düzenlenen Adliyeye Karşı Suçlar - Iftira, Suç Uydurma, Suç Üstlenme, Yalan Tanıklık ve Bilirkişilik, İnfaz Kurumlarından Kaçma (5th edn, Seçkin Yayıncılık 2019) 391.
} 
Kanımca suç ile bildirim yükümlülüğüne konu suçla korunan hukuksal değerin korunduğu görüşü belirli hallerde haklı olabilse de TCK m 280'in öncelikli olarak koruduğu değer bu değildir. Kimi durumlarda sağlık mesleği mensubunun henüz işlenmesi devam etmekte veya tamamlanmış ama sona ermemiş suçları bildirmesi ve böylece bildirime konu suçun engellenmesi mümkündür. Bu gibi durumlarda TCK m 280'in bildirim konusu suçla aynı hukuksal değeri koruma altına aldığı doğrudur. Örneğin sürmekte olan bir kişinin hürriyetinden yoksun birakılması suçunu öğrenen hekimin bildirimi üzerine kurtarılan kişinin hürriyeti bildirim ile korunmuştur. Ancak daha çok karşılaşılacak durum hekimin bildirdiği suçun zaten sona ermiş olmasıdır. Böylesi durumlarda ise bildirim konusu suçun koruduğu hukuksal değer zaten ihlal edilmiştir. Yine aynı örnek düşünülürse, kişinin hürriyetinden yoksun bırakılması suçu sona ermişse bu suça ilişkin bildirim ile kişi hürriyetinin bildiriminin korunması olası görünmemektedir. Benzer şekilde, TCK m 280'in işlenmekte veya tamamlanmış olan suçlara ilişkin bir bildirim yükümlülüğü ortaya koyduğu, buna karşılık yükümlülüğün hazırlık aşamasında olan yani icrasına henüz başlanmamış suçlar açısından bulunmadığına dikkat edilmelidir. Bu durum da suç ile korunan hukuksal değerin işlenmesi planlanan veya işlenmek için hazırlanılan suçla aynı hukuksal değer olmadığını gösterir. Bu sebeplerle bildirim konusu suçla bildirmeme suçunun koruduğu hukuksal değerlerin çoğu zaman birbirinden ayrıştığını kabul etmek gerekecektir.

Aynı şekilde bu suç ile adil yargılanma hakkının korunduğunu öne sürmek hatalı olacaktır. Zira adil yargılanma hakk1, Anayasa Mahkemesi ("AYM") 13 ve Avrupa İnsan Hakları Mahkemesi ("AİHM")14 kararlarında da görüleceği üzere, soruşturma ve kovuşturma makamlarının bir suçun işlendiğini öğrenmelerinden sonra devreye giren, hakkında bir suç isnadı bulunan kişinin yararlanabileceği bir haktır. Adil yargılanma hakkı ile suçlanan kişinin hukuka ve hakkaniyete uygun bir yargılama sürecine tabi tutulması amaçlanmaktadır. TCK m 280 ise hakkında suçlama bulunan kişiye ilişkin bir düzenleme değildir. Aksine, TCK m 280 ile suçların ortaya çıkarılması, yargılamanın yapılabilmesi ve suçluların cezalandırılmasının amaçlandığını söylemek mümkündür. Bu değer ise adil yargılanma hakkına değil, devletin temel haklara dair pozitif yükümlülükleri arasında yer alan etkili soruşturma yükümlülüğüne denk düşmektedir ${ }^{15}$. Gerçekten, adil yargılanma hakkının suç mağdurları bakımından izdüşümü olarak nitelendirilebilecek etkili soruşturma

\footnotetext{
B.E. Başvurusu, AYM, B. No: 2012/625, 09.01.2014, par. 26; Cevdet Genç Başvurusu, AYM, B. No: 2012/142, 09.01.2014, par. 44; Nevruz Bozkurt Başvurusu, AYM, B. No: 2013/664, 17.09.2014, par. 25.

14 Eckle/Almanya, AİHM, B. No: 8130/78, 15.07.1982; Deweer/Belçika, AİHM, B. No: 6903/75, 27.02.1980; Weber/İsviçre, AïHM, B. No: 11034/84, 22.05.1990.

15 Fatma Gökot Başvurusu, AYM, B. No: 2013/5697, 21.04.2016, par. 22. AYM'nin bu yükümlülüğü açıkladığı ve incelediği örnek bir karar için bkz. Serpil Kerimoğlu ve Diğerleri Başvurusu, AYM, B. No: 2012/752, 17.09.2013, par. 54 vd. Etkili soruşturma yükümlülüğüne ilişkin değerlendirme için bkz. Levent Emre Özgüç, 'Bireysel Başvuru İçtihatlarında Yaşam Hakkının Usuli Boyutu: Etkili Soruşturma Yükümlülüğ̈’' (2016) 10 Güncel Hukuk 32; Cem Şenol, Avrupa İnsan Hakları Mahkemesi Kararlarında Etkin Soruşturma Yükümlülüğ̈̈ (CMK m 172/3) (On İki Levha Yayıncılık 2013); Mark W Janis, Richard S Kay and Anthony W Bradley, European Human Rights Law (Oxford University Press 2008) 147-153; Ulaș Karan, 'Yaşam Hakkı' in Sibel İnceoğlu (ed), Insan Hakları Avrupa Sözleşmesi ve Anayasa (Avrupa Konseyi 2013); Durmuş Tezcan and others, Insan Hakları El Kitabı (8th edn, Seçkin Yayıncılık 2019) 122-133.
} 
yükümlülüğü, devletin suçlara ilişkin yargılamayı etkili bir biçimde yaparak makul sürede maddi gerçeğe ulaşması ve gerekli yaptırımları uygulaması gerekliliğine verilen isimdir. TCK m 280 ile soruşturma ve kovuşturma makamlarının bir suçun işlendiğinden ve bu suça ilişkin belirti ve ilgili hususlardan hızlıca haberdar olması, böylece deliller henüz ortadan kaybolmadan ve suç takibi zorlaşmadan soruşturma ve kovuşturmayı yapabilmesi amaçlanmaktadır.

Açıklanan sebeplerle; TCK m 280 ile suçların cezasız kalmaması, soruşturma ve kovuşturmanın mümkün olan en etkili şekilde yapılması, adli makamların suça ilişkin delil teşkil edebilecek belirti ve emarelerden haberdar edilmesi yoluyla cezaların konmasındaki amacın gerçekleştirilebilmesi ve kamu düzeninin sağlanması hedefleri güdülmektedir. Bu hedeflere ulaşılabilmesi adına, suç ile devletin etkili soruşturma yükümlülüğ̈̈ çerçevesinde adli fonksiyonların etkililiği değerinin korunduğunu söylemek doğru olacaktır.

\section{Tipikliğin Objektif (Maddi) Unsurları}

\section{A. Suçun Konusu}

Suçun konusu, suç tanımına uygun fiilin yöneldiği ve bu fiilin nesnesini oluşturan insan veya eşyadır ${ }^{16}$. İcrai hareketli suçlarda üzerinde suç tanımında yer alan icrai hareketin gerçekleştirildiği şey, ihmali hareketli suçlarda ise ihmal edilen yükümlülüğün üzerinde icrai hareketin gerçekleştirilmesini emrettiği şey suçun konusunu oluşturur ${ }^{17}$.

Doktrinde TCK m 280'in konusuna dair iki temel görüşün ileri sürüldüğü görülmektedir. Katıldığım ilk görüşe göre konu sağlık mesleği mensubunun belirtisiyle karşılaştığ suç ${ }^{18}$, veya suç teşkil eden ve bildirime konu olan vakıa veya belirtidir $^{19}$. Ancak bir diğer görüş suçun konusunun adli faaliyetler ve adliyenin işleyişi olduğu yönündedir ${ }^{20}$.

TCK m 280'de sağlık mesleği mensubuna görevi sırasında belirtisiyle karşılaştığ 1 suçu bildirmesi emredilmiştir. Bu suçta bildirim yükümlülüğünün konusunu oluşturan, yani hüküm tarafından yapılması emredilen fiilin yöneldiği şey, bildirilmesi gereken suçtur. Bu sebeple TCK m 280'in konusunun belirtilerin işaret ettiği ve sağl1k mesleği mensubunun yetkili makamlara bildirmesi gereken suç olduğunu kabul etmek gerekir.

\footnotetext{
6 Bu kavram kimi yazarlar tarafindan suçun maddi konusu veya hareketin konusu biçiminde de kullanılmaktadır. Nur Centel, Hamide Zafer and Özlem Çakmut, Türk Ceza Hukukuna Giriş (10th edn, Beta Yayınevi 2017) 232; Timur Demirbaş, Ceza Hukuku Genel Hükümler (13th edn, Seçkin Yayıncılık 2018) 559; Mahmut Koca and İlhan Üzülmez, Türk Ceza Hukuku Genel Hükümler (10th edn, Seçkin Yayıncılık 2017) 116.

17 Mehmet Emin Artuk and others, Ceza Hukuku Genel Hükümler (11th edn, Adalet Yayınevi 2017) 307.

18 Yağlıdere (n 7) 66; Necati Meran, Açıklamalı-İçtihatlı Yeni Türk Ceza Kanunu (2nd edn, Seçkin Yayıncılık 2007) 1341.

19 Koca and Üzülmez (n 10) 946.

20 Ümit Kocasakal, Suçu Bildirmeme Suçları (1st edn, Vedat Kitapçılık 2017) 179.
} 


\section{B. Fail}

TCK m 280'de düzenlenen suçun faili sağlık mesleği mensubudur. Suç tanımında failin belirli bir sıfata sahip olması arandığından özgü suç söz konusudur. Sağlık mesleği mensubu kavramı TCK m 280/2'de kanun koyucu tarafından açıklanmıştır: "Sağlık mesleği mensubu deyiminden tabip, diş tabibi, eczacı, ebe, hemşire ve sağlık hizmeti veren diğer kişiler anlaşılır." Sağlık hizmeti veren diğer kişilerin de suç faili olabileceğinin belirtilmesinden de anlaşılabileceği üzere, yapılan sayım sınırlayıcı nitelikte değildir. Madde gerekçesinde de bu husus dile getirilerek örneğin tıbbi tahlil laboratuvarında görev yapan kişilerin de suç faili olabileceği ifade edilmiştir. Ancak maddenin içeriğinden veya bağlayıcı olmasa da madde gerekçesinden sağlik mesleği mensubu kavramının kimleri kapsadığını anlamak mümkün olmamaktadır. Bu husus ve özellikle veteriner hekimlerin bu suçun faili olup olamayacağının doktrinde oldukça tartışmalı bir konu olduğunun altını çizmek gerekir. Kimi yazarlar doğrudan veya dolaylı olarak sağlık hizmeti veren herkesin bu suçun faili olabileceğini öne sürmüş ve veteriner hekimlerin de suç kapsamında olduğunu belirtmiştir ${ }^{21}$. Karş1 görüşte olanların bir kısmı bu suç çerçevesinde sağlık kavramının insan sağlığı olarak anlaşılması gerektiğinden ${ }^{22}$, diğerleri ise suçla korunan hukuksal yararın adliye olduğu ve hukukumuzda hayvanlara karşı suç işlenemeyeceğinden ${ }^{23}$ yola çıkarak hayvan sağlığıyla ilgilenen veteriner hekimlerin suçun faili olamayacağını savunmuşlardır.

Sağlık mesleği mensubu kavramının hangi sıfatları kapsadığının anlaşılabilmesi için bu konudaki mevzuata bakmak gerekir. Sağlik mesleği ve sağlik hizmetlerine ilişkin temel düzenleme 1928 yılında yürürlüğe girmiş 1219 sayılı Tababet ve Şuabatı San'atlarının Tarzı İcrasına Dair Kanun' da $^{24}$ yer almaktadır. Bu kanunda tababet, yani tıp mesleğinin icrasına dair genel kurallar belirtilmiş olmakla beraber; tabipler, diş tabipleri, ebeler, hastabakıcı hemşirelere ilişkin başlıklara yer verilmiş, ayrıca Ek Madde 13 'te çeşitli sağlık mesleği mensuplar. $1^{25}$ sayılmıştır ${ }^{26}$. Bu kanunun yanında, 657 sayılı Devlet Memurları Kanunu ${ }^{27}$ m 36’da "Sağlık Hizmetleri ve Yardımcı

\footnotetext{
${ }_{21}$ Tezcan, Erdem and Önok (n 7) 1256; Yağlıdere (n 7) 65; Ünver, ‘TCK'da Sağlık Personelinin Ceza Hukuku Sorumluluğuna Yol Açabilecek Hükümler' (n 13) 103; Ünver, TCK'da Düzenlenen Adliyeye Karşı Suçlar - İttira, Suç Uydurma, Suç Üstlenme, Yalan Tanıklık ve Bilirkişilik, Infaz Kurumlarından Kaçma (n 13) 394.

22 Zafer (n 8) 1335; Çakmut (n 7) 1052; Öget (n 9) 62.

23 Kocasakal (n 21) 178.

24 11.04.1928 tarihli ve 1219 sayılı Tababet ve Şuabatı San'atlarının Tarzı İcrasına Dair Kanun. Resmi Gazete: 14.04.1928/863.

251219 sayılı Kanun Ek Madde 13’te yer alan sıfatlar şu şekildedir: klinik psikolog, fizyoterapist, odyolog, diyetisyen, dil ve konuşma terapisti, podolog, sağlık fizikçisi, anestezi teknisyeni/teknikeri, tıbbi laboratuvar ve patoloji teknikeri, tıbbi laboratuvar teknisyeni, tıbbi görüntüleme teknisyeni/teknikeri, ağız ve diş sağlığı teknikeri, diş protez teknikeri, tıbbi protez ve ortez teknikeri/teknisyeni, ameliyathane teknikeri, adli tıp teknikeri, odyometri teknikeri, diyaliz teknikeri, fizyoterapi teknikeri, perfüzyonist, radyoterapi teknikeri, eczane teknikeri, iş ve uğraşı terapisti (ergoterapist), elektronörofizyoloji teknikeri, mamografi teknikeri, acil tıp teknikeri, hemşire yardımcısı, ebe yardımcısı, sağlık bakım teknisyeni.

26 Sağlık mesleği mensubu kavramının yorumlanmasında 1219 sayılı Kanun Ek m 13'ün dikkate alınacağına dair aynı yönde bkz. Rahime Erbaş, Türk Hukukunda ve Karşılaştırmalı Hukukta Sağlık Mesleği Mensuplarının Suçu Bildirme Yükümlülüğü (On İki Levha Yayıncılık 2015) 12; Öget (n 9) 62; Çakmut (n 7) 1052.

27 14.07.1965 tarihli ve 657 sayıl1 Devlet Memurları Kanunu. Resmi Gazete: 23.07.1965/12056.
} 
Sağlık Hizmetleri Sınıfı[na]" dahil meslekler listelenmiştir ${ }^{28}$. Her ne kadar 1219 sayılı Kanun'da veteriner hekimlerin yer almaması bu mesleğin sağlık mesleği olarak değerlendirilemeyeceği biçiminde yorumlanabilirse de 657 sayılı Kanun'da veteriner hekimler de sağllk personeli olarak belirlenmiştir. Bu sebeple veteriner hekimlerin de TCK m 280'de yer alan suçun faili olabileceğini belirtmek gerekir.

Ayrıca ifade edilmelidir ki; hukukumuzda hayvanlara karşı suç işlenemeyecek olduğu ve bu sebeple veteriner hekimlerin TCK $\mathrm{m} 280$ 'in faili olamayacakları görüşü iki açıdan hatalı bir sonuca varmaktadır. İlk olarak, 5237 sayılı TCK m 151'de yer alan "Mala Zarar Verme" suçunun konusunun sahipli hayvan olabileceği ilgili maddede açıkça dile getirilmiştir ${ }^{29}$. Hayvanlar her ne kadar suç mağduru olamasalar da suç konusu oluşturabilmektedirler ${ }^{30}$. İkinci olarak, veteriner hekimlerin yalnızca "hayvanlara karşı" işlenen bir suçu bildirmekle yükümlü olduğunu görüşü de doğru değildir. Bir veteriner hekimin karşılaşabileceği kimi olaylarda hayvanın suçta araç olarak kullanılmış olması da mümkündür. Örneğin bir köpeğin bir başkasının üzerine saldırtılması suretiyle yaralama suçunun işlenmesi halinde, veteriner hekim bu köpeği tedavi ederken bu yaralama suçunun belirtilerini görürse bu suçu bildirmekle yükümlü olacaktır.

Suçun faili olabilecek meslek grupları açısından belirtilmesi gereken bir diğer nokta, tıp literatüründe geleneksel veya tamamlayıcı tıp uygulamaları adı verilen akupunktur, sülük tedavisi, kupa tedavisi, kayropraktik gibi uygulamaları yapan kişilerin durumudur. Bu sıfatlara sahip kişiler de insan sağllğına ilişkin bir hizmet vermekte ve Sağlık Bakanlığı mevzuatı içerisinde açıkça "sağlık meslek mensubu" olarak tanımlanmış bulunmaktalardır. Bu sebeple bu suçun faili olabileceklerdir ${ }^{31}$.

İfade etmek gerekir ki; TCK m 280'de suçu işleyebilecek kişileri ifade eden "sağlık hizmeti veren diğer kişiler" düzenlemesi, suç tanımının kapsamını oldukça muğlak hale getirmektedir ve kanunilik ilkesi bakımından son derece sorunludur.

28657 sayılı Kanun m 36'nın ilgili kısmı şu şekildedir: "Bu sınıf, sağlık hizmetlerinde (Hayvan sağlığı dahil) mesleki eğitim görerek yetişmiş olan tabip, diş tabibi, eczacı, veteriner hekim gibi memurlar ile bu hizmet sahasında çalışan yüksek öğrenim görmüş fizikoterapist, tıp teknoloğu, ebe, hemşire, sağlık memuru, sosyal hizmetler mütehassısı, biyolog, pisikolog, diyetçi, sağlık muhendisi, sağlık fizikçisi, sağlık idarecisi ile ebe ve hemşire, hemşire yardımcısı, (Fizik tedavi, laboratuvar, eczacı, diş anestezi, röntgen teknisyenleri ve yardımcıları, çevre sağlığı ve toplum sağlı̆̆ı teknisyeni dahil) sağlık savaş memuru, hayvan sağlık memuru ve benzeri sağlık personelini kapsar."

295237 sayılı TCK m 151: “(1) Başkasının taşınır veya taşınmaz malını kısmen veya tamamen yıkan, tahrip eden, yok eden, bozan, kullanılamaz hale getiren veya kirleten kişi, mağdurun şikayeti üzerine, dört aydan üç yıla kadar hapis veya adlî para cezası ile cezalandırılır. (2) Haklı bir neden olmaksızın, sahipli hayvanı öldüren, işe yaramayacak hale getiren veya değerinin azalmasına neden olan kişi hakkında yukarıdaki fikra hükmü uygulanır.”

30 Tezcan, Erdem and Önok (n 7) 767. Suç kapsamında yalnızca sahipli hayvanlara verilen zararın cezalandırılmasının temel sebebi suç ile mülkiyet hakkının korunuyor olmasıdır. Bkz. Tezcan, Erdem and Önok (n 7) 765; Nur Centel, Hamide Zafer and Özlem Çakmut, Kişilere Karşı İşlenen Suçlar Cilt: I (4th edn, Beta Yayınevi 2017) 426; Nevzat Toroslu, Ceza Hukuku Özel Kısım (5th edn, Savaş Yayınevi 2010) 155; Zeki Hafızoğulları and Muharrem Özen, Türk Ceza Hukuku Özel Hükümler Kişilere Karşı Suçlar (US-A Yayıncılık 2010) 342.

31 Söz konusu uygulamalara ilişkin esaslar 27.10.2014 tarihli ve 29158 sayılı Resmi Gazete'de yayımlanmış Geleneksel ve Tamamlayıcı Tıp Uygulamaları Yönetmeliği'nde düzenlenmiştir. Yönetmelik ekinde kimi uygulamaların tabip veya diş tabibi dışında sertifika sahibi kişilerce de yapılabileceği belirtilmişse de, bu kişilerin sağlık mesleği mensubu olduğu açıkça ortaya konmuştur. 
Ceza hukukunun temel kurallarından olan ve TCK m 2'de de açıkça ortaya konan suç ve cezada kanunilik ilkesi uyarınca suç düzenlemelerinin öngörülebilir ve belirli olmaları gerekir ${ }^{32}$. İlke uyarınca suçun faili olabilecek kişilerin örnekleyici sayımla belirlenmesi doğru değildir ve hükmün uygulanması konusunda belirsizliklere yol açabilecek niteliktedir. Doktriner tartışmaların yoğunluğu da bu belirsizliği gözle önüne sermektedir. Suç tanımının belirsizliği giderecek şekilde yeniden düzenlenmesi, sağlık mesleği mensubu kavramının sınırlarının kanunla ve belirlilik ilkesine uygun bir biçimde çizilmesi doğru olacaktır.

Suça ilişkin bir diğer sorun, kamu görevlisi olan ve özel sektörde veya serbest olarak çalışan sağlık mesleği mensuplarının bu suçun faili olup olamayacakları meselesidir. Sorunun kaynağı, TCK m 279 ve 280'de sırasıyla kamu görevlileri ve sağlık mesleği mensupları için benzer suçu bildirmeme suçlarının düzenlenmiş olması ve m 280 gerekçesinde kamu görevlisi sağlık mesleği mensupları hakkında "yukarıdaki madde hükmü[nün]" uygulanacağının belirtilmesidir ${ }^{33}$. Bu konuda doktrinde öne sürülen baskın görüş TCK m 280'in yalnızca özel sağlık kurum ve kuruluşlarında ya da serbest olarak çalışan sağlık meslek mensuplarına uygulanacağı, kamuda görev yapan sağlık meslek mensuplarının ise TCK m 279'a tabi olacağıdır. Bu görüşü benimseyen yazarlar TCK m 279'un m 280'e göre özel hüküm niteliğini taşıdığını düşünmektedirler ${ }^{34}$. Yargıtay'ın uygulaması baskın görüşe paralel gelişmiştir ${ }^{35}$. Doktrinde savunulan ikinci görüş ise kamu görevlisi olsun olmasın tüm sağlık mesleği mensuplarının TCK m 280 faili olabilecekleridir ${ }^{36}$. Son olarak, savunucusu çok olmayan bir görüş ise TCK m 280'in yalnızca kamu görevlisi sağlık mesleği mensuplarına uygulanacağı, özel sektörde veya serbest olarak çalışan sağlık mesleği mensuplarının ise ne TCK m 279, ne de m 280 uyarınca sorumlu tutulabileceğidir ${ }^{37}$.

Kanımca, madde gerekçesine dayanılarak kamu görevlisi sağlık mesleği mensuplarının TCK m 279'a, diğer sağlık mesleği mensuplarının ise m 280'e tabi tutulmaları gerektiği sonucuna varmak doğru değildir. Bu nedenle Yargıtay ve baskın

32 AYM içtihadında belirlilik ilkesine şu şekilde dikkat çekilmiştir: "Suçta ve cezada kanunilik ilkesi uyarınca, hangi fiillerin yasaklandığının ve bu yasak fiillere verilecek cezaların hiçbir kuşkuya yer bırakmayacak bir şekilde kanunda gösterilmesi, kuralın açık, anlaşılır ve sınırlarının belli olması gerekmektedir." AYM, E. 2014/120, K. 2015/23, 05.03.2015.

33 TCK m 280 Gerekçesi: “...Devlet eliyle işletilen sağlık kuruluşlarında görev yapan sağlık mesleği mensupları, kamu görevlisi sıfatını taşımaktadırlar. Bu kişilerin suçu bildirme yükümlülüğüne aykırı davranmaları hâlinde, yukarıdaki madde hükmü uygulanacaktır."

34 Çakmut (n 7) 1053; Yağlıdere (n 7) 64; Bulut (n 7) 86; Gültekin (n 7) 107; Kocasakal (n 21) 174; Koca and Üzülmez (n 10) 946; Meran (n 19) 1340; Hakeri (n 7) 1271; Osman Yaşar, Hasan Tahsin Gökcan and Mustafa Artuç, Yorumlu-Uygulamalı Türk Ceza Kanunu Cilt VI (Adalet Yayınevi 2010) 8041. Ancak Meran kamu görevlisi olup da suçtan haberdar olduğu sırada kamu görevi kapsamı dışında örneğin acil tedavi yapan sağlık mesleği mensubunun TCK m 280'e tabi olacağını belirtmektedir.

35 Y9CD, E. 2013/16353 K. 2014/6220, 15.05.2014: “...Devlet Hastanesinde doktor olan sanığın iddia ve kabul edilen suçu bildirmeme eyleminin TCK'nın 279. maddesinde yaptırıma bağlanan kamu görevlisinin suçu bildirmemesi suçunu oluşturacağı hukuki durumunun buna göre takdir ve tayini gerektiği gözetilmeden suç vasfinda yanılgıya düşülerek yazılı şekilde hüküm kurulması..."

36 İplikçi (n 7) 84; Ünver, TCK'da Düzenlenen Adliyeye Karşı Suçlar - Ifttira, Suç Uydurma, Suç Üstlenme, Yalan Tanıklk ve Bilirkişilik, İnfaz Kurumlarından Kaçma (n 13) 397; İsa Döner, 'Suçu Bildirmeme Suçu (TCK m 278)' (2005) 9 Ankara Üniversitesi Hukuk Fakültesi Dergisi 63, 72; Tezcan, Erdem and Önok (n 7) 1257; Ünver, 'TCK'da Sağlık Personelinin Ceza Hukuku Sorumluluğuna Yol Açabilecek Hükümler' (n 13) 104.

37 Arslan and Azizağaoğlu (n 7) 1123. 
doktriner görüşün hatalı olduğunu söylemek gerekir. Zira TCK m 280, suç failini özgülerken bu suçu işleyebilecek kişilerin belirli bir sıfata sahip olmalarını gerekli görmüş, bir sıfattan yoksun olmaları şartını ortaya koymamıştır ${ }^{38}$. Bu nedenle suç tanımından yola çıkarak kamu görevlilerini dışlamak hatalıdır. Gerekçenin böyle bir iradeyi ifade etmesi, hukukumuzda gerekçelerin bağlayıcı olmamaları ve hatta hükmün yorumunda ancak tali kaynak şeklinde kullanılabilecekleri düşünüldüğünde sorunun çözümünde belirleyici olmamalıdır. Böyle bir durumda, TCK m 279'un m 280'e göre öncelikli olarak uygulanacak olmasının tek yolu, bu hükümler arasında özel-genel hüküm ilişkisinin kurulabilmesidir. Bir kuralın diğer bir kurala göre özel hüküm teşkil etmesi, genel olarak kabul edilen hüküm ile aynı unsurlara sahip olmasının yanında, bu unsurlara bir diğerini eklemesi suretiyle olur ${ }^{39}$. Örneğin bir suçun nitelikli hali, basit haline göre özel hüküm niteliğindedir; nitelikli halin oluşması için basit hali oluşturan tüm unsurların ve bunlara ek bir başka unsurun gerçekleşmesi aranır ${ }^{40}$. Bu çerçevede TCK m 279 ve 280'e bakılırsa, m 279'un "kamu adına soruşturma ve kovuşturmayı gerektiren bir suçun işlendiğini göreviyle bağlantılı olarak öğrenip de yetkili makamlara bildirimde bulunmayı ihmal eden veya bu hususta gecikme gösteren kamu görevlisi[ni]" cezalandırdığı görülecektir. $\mathrm{Bu}$ düzenleme $\mathrm{m} 280$ ile failin sıfatı konusunda ayrışmaktadır. Ancak kamu görevlisi ve sağlık mesleği mensubu sıfatlarının herhangi birinin diğerini kapsayıcı olduğunu söylemek mümkün değildir. Kamu görevlisi olan veya olmayan sağlık mesleği mensupları olabileceği gibi, sağlı mesleği olan veya olmayan kamu görevlileri de vardır. Yani suçların faile ilişkin düzenlemeleri birbirilerinden tümüyle farklı, yalnızca kesişebilen iki kümeyi ilgilendirmektedir. Suçların arasında özellik ve genellik ilişkisi kurulamayacağının temel göstergesi budur.

Suçların aralarında böyle bir bağlantı olmadığını düşünmeye yol açan bir diğer neden, kamu görevlilerinin yalnızca kamu adına soruşturma ve kovuşturmayı gerektiren, yani re'sen takip edilen suçları bildirmekle yükümlü olmaları, buna karşılık sağlık mesleği mensuplarının tüm suçları bildirmekle yükümlü kılınmalarıdır. Eğer TCK m 279'un m 280'e göre özel hüküm olduğu iddia edilirse, kamu görevlisi sağlık mesleği mensuplarının kamusal herhangi bir sıfatı olmayan sağlık mesleği mensuplarından daha dar bir yükümlülüğe tabi tutuldukları sonucuna varılması gerekecektir ki; böyle bir görüşün anlamlı olduğunu savunmak zordur.

Açıklanan nedenlerle, ne TCK m 279'un, ne de $m$ 280'in diğerine göre özel hüküm olmadığını ve bir diğerinin uygulama alanını sınırlamadığını kabul etmek gerekir ${ }^{41}$.

\footnotetext{
38 Aynı yönde bkz. Ünver, ‘TCK'da Sağlık Personelinin Ceza Hukuku Sorumluluğuna Yol Açabilecek Hükümler' (n 13 ) 104.

39 Veli Özer Özbek and others, Türk Ceza Hukuku Genel Hükümler (8th edn, Seçkin Yayıncıllk 2017) 558; Kayıhan İçel, Suçların İçtimaı (Sermet Matbaası 1972) 187; Nevzat Toroslu and Haluk Toroslu, Ceza Hukuku Genel Kısım (21st edn, Savaş Yayınevi 2015) 86.

40 İçel (n 40) 188.

${ }^{41}$ Bu iki hükmün arasındaki ilişki suç ve cezaların içtimaı kurallarının uygulanmasıyla çözülecektir. Bu konuda bkz. VII.C. İçtima.
} 
Böyle bir durumda ise ortaya çıkan sonuç TCK m 279'un varlığının m 280'in fail unsurunun yorumunda dikkate alınmaması gerektiğidir. Sonuç olarak TCK m 280'in faili hem kamu görevi yapan hem de özel sektörde veya serbest olarak çalışan tüm sağlık mesleği mensupları olabilir.

Belirtilmesi gereken bir diğer husus, sağlık mesleği mensubunun bu suçun faili olması için bildirime konu suçun faili veya mağduru olmaması gerektiğidir. Örneğin taksirle öldürme suçunun faili olan bir hekimin, nemo tenetur se ipsum accusare (kişinin kendisini suçlamaya zorlanamaması) ilkesi nedeniyle bu suçu bildirme yükümlülüğü bulunmayacaktır ${ }^{42}$. Bildirim yükümlülüğünün ihlali bu durumda cezalandırılamayan sonraki hareket teşkil etmektedir ${ }^{43}$. Ayrıca kanunda açıkça böyle bir istisnaya yer verilmemiş olsa da bir suç mağduru olan hekimin eğer söz konusu suç şikayete bağlı ise ve hekim şikayette bulunmama kararı almış ise bu suçu bildirmekle yükümlü olmadığını söylemek gerekir ${ }^{44}$. Son olarak, suçu bildirmeyen sağlık mesleği mensubunun bildirimin konusu suç neticesini önlemekle yükümlü, yani garantör olması durumunda da TCK m 280'in faili olmayacağını belirtmek gerekir. Zira bu durumda da sağlık mesleği mensubu bildirim konusu suçun faili olacaktır ${ }^{45}$.

\section{Fiil ve Netice}

TCK m 280'de düzenlenen suçun fiil unsuru, görev sırasında suç işlendiği yönünde belirtiyle karşılaşılmasına rağmen durumun yetkili makamlara bildirilmemesi veya bildirimde gecikilmesidir.

Suçun oluşması failin bildirim yükümlülüğünü gerçekleştirmemesi veya geç gerçekleştirmesi, yani kanun tarafından yapılması emredilen icrai hareketi yapmayı ihmal etmesi ile oluştuğundan gerçek ihmali hareketli suçtur ${ }^{46}$. Bu suç aynı zamanda seçimlik hareketli bir suçtur, zira failin bildirimi hiç yapmaması veya gecikerek yapması hareketlerinden birinin yapılmasıyla suç tamamlanır.

Suç, bildirim yükümlülüğünün ihmaliyle tamamlandığı için salt hareket suçudur. Ayrıca bildirim yükümlülügün̈nde bulunmamanın suçun oluşumu için yeterli görülmesi ve kanunda bir başka zarar veya tehlike neticesi aranmaması nedeniyle suçun bir soyut tehlike suçu olduğunu belirtmek gerekir ${ }^{47}$.

\footnotetext{
42 Bu konuda bkz. V.A. Susma Hakkı.

43 Cezalandırılmayan sonraki harekete ilişkin bilgi için bkz. Kayıhan İçel, 'Görünüşte Birleşme (İçtima) İlkeleri ve Yeni Türk Ceza Kanunu’ (2008) 7 İstanbul Ticaret Üniversitesi Sosyal Bilimler Dergisi 35, 43.

44 Tezcan, Erdem and Önok (n 7) 1256.

45 Tezcan, Erdem and Önok (n 7) 1246; Erdem (n 11) 108. Yazarlar bu görüşü TCK m 278'de yer alan faili özgü olmayan suçu bildirmeme suçu için öne sürmüş olsalar da aynı durum TCK m 280 için de geçerlidir.

46 Üzülmez (n 10) 827; Artuk and Gökcen (n 18) 257. Alman CK'da da benzer bir yükümlülüğü içeren m 138'in gerçek ihmali suç olduğu yönünde bkz. Bernd Heintschel-Heinegg, Strafgesetzbuch Kommentar (Verlag CH Beck 2010) 993; Karl Lackner and Kristian Kühl, Strafgesetzbuch Kommentar (26th edn, Verlag CH Beck 2007) 663; Wolfgang Joecks, Studienkommentar Strafgesetzbuch (9th edn, Verlag CH Beck 2010) 240.

47 Tezcan, Erdem and Önok (n 7) 1255; Zafer (n 8) 1342; Yağlıdere (n 7) 66; Bulut (n 7) 88; İplikçi (n 7) 87; Ünver, TCK'da Düzenlenen Adliyeye Karşı Suçlar - İftira, Suç Uydurma, Suç Üstlenme, Yalan Tanıklık ve Bilirkişilik, İnfaz Kurumlarından Kaçma (n 13) 393; Kocasakal (n 21) 167.
} 
İhmali hareketli bir suçun fiil unsurunun icrai hareket yükümlülüğ̈nün doğması ve bu yükümlülüğün fail tarafından yerine getirilmemesi biçiminde iki farklı parça halinde incelenmesi mümkündür. TCK m 280'in fiil unsurunun oluşması için, öncelikle sağl1k mesleği mensubunun suçu bildirme yükümlülüğünün doğması, daha sonra sağlı mesleği mensubunun bu yükümlülüğe aykırı olarak yetkili makamlara bildirim yapmaması veya bildirimi geç yapması gerekmektedir. Bu kısımda fiil unsurunun incelenmesi de bu ayrıma dikkat edilerek yapılmıştır.

\section{Bildirim Yükümlülüğünün Doğması}

Belirtildiği üzere, sağlık mesleği mensubunun TCK m 280'de yer alan suçtan sorumlu tutulması için hükmün konusunu oluşturan suçu bildirme yükümlülüğünün doğmuş olması gerekir. Bu yükümlülüğün doğması belirli koşulların gerçekleşmesine bağlıdır. Bunlar; bir suçun işlenmiş veya işlenmekte olması, sağlık mesleği mensubunun bu suçun işlendiği yönünde bir belirtiyle karşılaşması, bu karşılaşmanın sağlı mesleği mensubunun görevi sırasında gerçekleşmesidir. Aşağıda bu koşulların her biri açıklanmaktadır.

\section{a. Bir Suçun İşlenmiş Olması}

Öncelikle, bildirim yükümlülüğünün oluşması için ortada belirtisiyle karşılaşılan bir suçun bulunması gerekir. 765 sayılı mülga Türk Ceza Kanunu'ndan farklı olarak, TCK m 280'de suçun niteliğine ilişkin herhangi bir sınırlama yapılmamıştır ${ }^{48}$. Bu sebeple bildirim konusu olan suçun yöneldiği hukuksal değer, suçun mağduru, ağırlığ1 veya temel veya yan ceza kanunlarında yer almasının önemi yoktur ${ }^{49}$. Aynı şekilde, doktrinde aksi öne sürülmüş olsa da ${ }^{50}$ suçun re'sen veya şikâyet üzerine soruşturulan ve kovuşturulan bir suç olması bildirim yükümlülüğünün doğumu bakımından önem taşımaz $^{51}$, zira bildirim yükümlülüğünün oluşması için şikâyet gibi dava şartlarının varlığının aranması kanunda yer almayan bir sınırlama ile suç kapsamının daraltılması olacaktır. Ancak şikâyete bağlı suçların bildirim yükümlülüğü kapsamına alınmasının şikâyet kurumunun amacına aykırı olduğunun haklı olarak öne sürüldüğüne de dikkat çekmek gerekir ${ }^{52}$.

765 sayılı mülga Türk Ceza Kanunu'ndaki ilgili hüküm ile TCK m 280 arasındaki bir diğer fark, bildirim yükümlülüğüne konu suçun failinin sağlık mesleği mensubunun hizmet sunduğu kişi olup olmaması bakımından herhangi bir ayrıma gidilmemiş olmasıdır. 765 sayılı Kanun m 530'da bildirim yükümlülüğüne “bu

\footnotetext{
765 sayılı mülga TCK m 530'da ise bildirilecek suçun “şahıslar aleyhinde işlenmiş bir cürüm” olması gerekmekteydi.

49 Yağlidere (n 7) 61; Koca and Üzülmez (n 10) 948.

so Kocasakal (n 21) 183.

51 Tezcan, Erdem and Önok (n 7) 1257; Zafer (n 8) 1331, 1342; Ünver, 'TCK'da Sağl1k Personelinin Ceza Hukuku Sorumluluğuna Yol Açabilecek Hükümler' (n 13) 105; Çakmut (n 7) 1054; İplikçi (n 7) 78.

$52 \quad$ Zafer (n 8) 1341; Bulut (n 7) 87.
} 
ihbar kendisine yardım ettikleri kimseyi takibata maruz kılacak ahval müstesna olmak üzere" biçiminde bir istisna getirilmek suretiyle hastasının suç faili olduğu durumlarda hekime bildirim yükümlülüğü yüklenmemişti. Ancak 5237 sayılı Türk Ceza Kanunu'nda böyle bir düzenleme tercih edilmemiştir. Bu sebeple, doktrinde de kabul edildiği üzere sağlık mesleği mensubu, yardım ettiği kişinin suçun faili olmasına bakmaksızın bildirimde bulunmak zorundadır. Aynı durum hasta veya yardım edilen kişinin suç mağduru olduğu hallerde de geçerlidir ${ }^{53}$.

TCK m 280'de yer alan suç tanımında; bildirilmesi gereken suçun niteliği, bu suçun re'sen takip edilen bir suç olup olmaması veya bu suç için öngörülen cezanın ağırlığı bakımından herhangi bir sınırlamaya gidilmemiş olmasının eleştirilebilir bir nokta olduğunu ifade etmek gerekir. Türk hukukuna benzer bir yükümlülüğün ihlalinin suç olarak düzenlendiği Alman CK m 138'de bildirim yalnızca belirli suçlar bakımından öngörülmüştür. İlgili hükme göre bildirim yükümlülügü yalnızca saldırı savaşının hazırlanması suçu, öldürme, soykırım, insanlığa karşı suçlar, savaş suçları, kişi özgürlüğüne karşı suçlar, yağma, şantaj ve genel güvenliğe karşı belirli suçların öğrenilmesi halinde mevcut olacaktır. Kişinin bir başka suça ilişkin bir bilgi edinmesi halinde ise genel bir suçu bildirim yükümlülüğünün mevcut olmayacağı doktrinde açıkça dile getirilmiştir ${ }^{54}$.

Türk hukukunda sağlık mesleği mensubuna görevi sırasında belirtisiyle karşılaştı̆̆ her suçu bildirme yükümlülüğünün yüklenmiş olması ve hatta bu suçların faili veya mağdurunun sağlık mesleği mensubu tarafından tedavi edilen kişi olması bakımından herhangi bir ayrım yapılmamış olmasının tedaviye erişim açısından da oldukça sorunlu bir durum olduğu ifade edilmelidir. Bu düzenlemeye göre, örneğin baskıcı bir aile yapısından gelen bir kadın cinsel saldırı mağduru olmasının ardından hastaneye tedavi olmaya geldiğinde, bunu öğrenen hekimin mağdur kadının aksi yöndeki iradesini tümüyle göz ardı ederek suçu bildirmesi gerecektir. Bu olayda kadının durumunun ailesi tarafından öğrenilmesi halinde öldürülmekten korktuğunu söylemesi bile hiçbir sonuç doğurmayacak, hatta kadının yaşamı için korktuğundan dolayı suçu bildirmeyen hekim hapis cezasıyla tehdidiyle karşı karşıya kalabilecektir! Başka bir örnek vermek gerekirse, istemediği çocuğunu yasadışı yollardan kendisi düşürmeye çalışan kadın, bu konuda başarısız olur ve sağlığı tehlikeye girerse, buna rağmen tedavi amaciyla hastaneye gitmek istemeyebilecektir. Zira kendisini tedavi edecek hekim kadını TCK m 100'ü işlediği şüphesiyle ihbar etmek zorundadır ${ }^{55}$. $\mathrm{Bu}$ gibi örneklerin yaşanabileceği ülkemizde elbette karşılaşılması ihtimal dahilinde bir sonuç, suç faili veya mağduru olan bireylerin konunun muhakeme konusu

\footnotetext{
Zafer (n 8) 1332; Yağlıdere (n 7) 68; Çakmut (n 7) 1060; Ünver, ‘TCK’da Sağlık Personelinin Ceza Hukuku Sorumluluğuna Yol Açabilecek Hükümler' (n 13) 106.

54 Schönke and Schröder (n 12) 1451; Fischer (n 12) 962.

55 Aynı konuda Hakeri’nin verdiği örnek de oldukça dikkat çekicidir: "Örneğin 17 yaşında resmi nikahı bulunmayan bir kadının, hamile kalıp kadın doğum uzmanına muayeneye gittiği hallerde, hekimin kadın şikayet etmese bile, bu durumu bildirme yükümlülüğü bulunmaktadır.” Hakeri (n 7) 1273.
} 
yapılmaması için tedavi olmamayı seçmeleri ve sağlıklarının ciddi riske girmesidir. Böyle bir sonucun insan haklarına saygılı bir hukuk devletinde ne ölçüde kabul edilebilir olduğu ise şüphelidir.

Belirtilmesi gereken bir diğer konu, TCK m 280'de yer alan bildirim yükümlülügüne konu suçların kapsamının aslında tıp literatüründe "adli vaka" olarak ifade edilen durumlardan daha geniş olduğudur. Uygulamada "adli vaka" "dış etken sonucu meydana gelen tüm yaralanmalar" olarak tanımlanmakta ve genellikle hasta aleyhine işlendiği hastanın üzerinden doğrudan anlaşılabilen, öldürme, yaralama, cinsel saldırı, cinsel istismar, işkence, eziyet gibi suçları kapsamaktadır ${ }^{56}$. Tıp uygulaması böyle gelişmişse de TCK m 280'de yer alan bildirim yükümlülüğünün kapsamı, açıklandığı üzere her suçu kapsamaktadır.

Bildirim niteliğine konu fiilin bir suç teşkil etmesi gerektiğinden; haksız fiil, kabahat veya disiplin yaptırımı sonucu doğuran ihlallerin belirtileriyle karşılaşan sağlık mesleği mensubu, bunları bildirmekle yükümlü değildir ${ }^{57}$. Aynı şekilde, ilgili fiilin meşru savunma veya hakkın icrası gibi bir nedenin bulunması dolayısıyla hukuka uygun hale gelmiş olması durumunda da suçun unsurları oluşmamış olduğundan bildirim yükümlülüğü doğmaz ${ }^{58}$. Ancak, günümüzde doktrinin baskın olarak kabul ettiği görüş uyarınca suçun sübjektif unsurundan bağımsız nitelik kazanmış ve kişinin kınanabilirliğini ifade eden kusurluluğun ${ }^{59}$ ortadan kalkması halinde de fiil suç teşkil edeceği için bildirimin yapılması gerekecektir ${ }^{60}$. Buna göre, örneğin kusur yeteneği olmayan bir akıl hastasının yaralama teşkil eden fiilinin bildirilmemesi halinde TCK m 280 uygulama alanı bulacaktır. Buna karşılık kusurluluğun suçun bir unsuru olduğunu ifade eden diğer görüşe göre ise kusurluluğu kaldıran yaş küçüklüğü, akıl hastalığı gibi durumların varlığı bildirim yükümlülügüünün ortaya çıkmasını engelleyecektir ${ }^{61}$. Böyle bir durumda suçun oluşmayacağ1 görüşünün kabulünün mümkün olmadığını belirtmek gerekir. Zira suçu işleyen kişinin kusur yeteneği olmasa dahi bu durumun 5271 sayılı Ceza Muhakemesi Kanunu ("CMK") m 74 uyarınca mahkeme tarafından tespit edilmesi ve muhakemenin bu şekilde sonlandırılması gerekir. Ancak kusur yeteneği suçun unsuru ise ve sağlık mesleği

\footnotetext{
56 Alper Keten and others, 'Acil Serviste Düzenlenen Adli Raporların Türk Ceza Kanunu Kapsamında Değerlendirilmesi' (2011) 5 Turkish Medical Journal 94, 95.

57 Tezcan, Erdem and Önok (n 7) 1257; Zafer (n 8) 1341; Ünver, TCK'da Düzenlenen Adliyeye Karşı Suçlar - İftira, Suç Uydurma, Suç Üstlenme, Yalan Tanıklık ve Bilirkişilik, Infaz Kurumlarından Kaçma (n 13) 405; Kocasakal (n 21$) 180$.

58 Ancak böyle bir durumu sağlık meslek mensubunun takdir etmesine imkan yoktur, eylemin hukuka aykırı olup olmadığını yapılacak yargılamada mahkeme belirleyecektir. Bu sebeple sağlık mesleği mensubunun suç teşkil ettiği yönünde şüphesinin bulunduğu tüm fiilleri bildirmesi TCK m 280 dolayısıyla sorumlu tutulması ihtimalini azaltacağından faydalı olacaktır.

59 Koca and Üzülmez (n 17) 83; Özbek and others (n 40) 333; Berrin Akbulut, Ceza Hukuku Genel Hükümler (5th edn, Adalet Yayınevi 2018) 524; İzzet Özgenç, Türk Ceza Hukuku Genel Hükümler (14th edn, Seçkin Yayıncılık 2018) 390; Artuk and Gökcen (n 18) 493.

${ }^{60}$ Ünver, TCK'da Düzenlenen Adliyeye Karşı Suçlar - Iftira, Suç Uydurma, Suç Üstlenme, Yalan Tanıklık ve Bilirkişilik, Infaz Kurumlarından Kaçma (n 13) 405.

${ }_{61}$ Centel, Zafer and Çakmut (n 17) 215; Demirbaş (n 17) 211; Bahri Öztürk and Mustafa Ruhan Erdem, Uygulamalı Ceza Hukuku ve Güvenlik Tedbirleri Hukuku (16th edn, Seçkin Yayıncılık 2016) 156.
} 
mensubunun tedavi ettiği kişi bir akıl hastasıysa, bu durumda suç ve dolayısıyla bu suçu bildirim yükümlülüğü bulunmayacaktır. Bu görüşe katılmak ise oldukça zordur.

Bildirim yükümlülüğünün ortaya çıkması bakımından özellik taşıyan tek suç, TCK m 191'de yer alan "Kullanmak için uyuşturucu veya uyarıcı madde satın almak, kabul etmek veya bulundurmak ya da uyuşturucu veya uyarıcı madde kullanmak" suçudur. Kanunun suça ilişkin etkin pişmanlığı düzenleyen 192. maddesinin dördüncü fikrasına 2016 yılında eklenen cümleye ${ }^{62}$ göre uyuşturucu veya uyarıcı madde kullanan kişi, hakkında TCK m 191 hükmünden dolayı soruşturma başlatılmadan önce resmi makamlara veya sağlık kuruluşlarına başvurarak tedavi ettirilmesini isterse, başvurunun yapılmasının ardından bu suça ilişkin belirtiyle karşılaşan sağlık mesleği mensubunun bildirim yükümlülüğü doğmayacaktır ${ }^{63}$. Kanun bildirim yükümlülüğünün doğmayacağından söz ettiği için bu durumun bir cezasızlık nedeni olmadığını, etkin pişmanlığın TCK m 280'in kapsamını daralttığını ifade etmek gerekir. Böyle bir durumda bildirim yapılmaması suçta tanımlanan tipik fiili oluşturmayacaktır.

Kişinin bildirimle yükümlü olması için ayrıca karşılaşılan suçun işlenmiş veya işlenmekte olması gerekir. Gerçekten, TCK m 280, sağlık mesleği mensubunun suçun "işlendiğii” yönünde belirtiyle karşılaşmış olmasını aramıştır. Bu sebeple, ilgili suçun en azından işlenmeye başlanmış, yani icra aşamasına gelmiş olması gerekmektedir ${ }^{64}$. Zira henüz icrasına başlanmamış bir suçun hukuk düzeninde varlığından söz etmek mümkün değildir; böyle bir durumda bir suç var olmayacağı için bu suçu bildirim yükümlülüğü de oluşmayacaktır ${ }^{65}$. Örneğin bir sağlık mesleği mensubunun gelecekte işlenmesi planlanan bir suçu görevi sırasında öğrenmesi, bu suç ne olursa olsun, TCK m 280 çerçevesinde bir bildirim yükümlülügüünün doğmasına neden olmayacaktır. Ancak icra hareketlerine başlanmış ise, hukuk düzenince yaptırıma tabi tutulmuş bir suçun varlığından söz edilir ki, bu anda fiil bildirim yükümlülüğüne konu hale gelir. Aynı şekilde, sona ermiş bir suçun belirtisiyle karşılaşan sağlık mesleği mensubunun da bildirim yükümlülüğü mevcuttur ${ }^{66}$. TCK m 280, m 278'de düzenlenen bildirmeme suçundan farklı olarak işlenmiş suçun neticelerinin sınırlandırılabilmesinin mümkün olmasını da gerekli görmemiştir ${ }^{67}$, bu nedenle suç sona ermiş ve hatta suçun sona

\footnotetext{
62 Ekleme 24.11.2016 tarihli ve 6736 sayılı Kanun m 16 ile yapılmıștır. TCK m 192'nin ilgili fikrası șu șekildedir: “(4) Uyuşturucu veya uyarıcı madde kullanan kişi, hakkında kullanmak için uyuşturucu veya uyarıcı madde satın almak, kabul etmek veya bulundurmaktan dolayı sorușturma bașlatılmadan önce resmi makamlara veya sağlık kurulușlarına başvurarak tedavi ettirilmesini isterse, cezaya hükmolunmaz. (Ek cümle: 24/11/2016-6763/16 md.) Bu durumda kamu görevlileri ile sağlık mesleği mensuplarının 279 uncu ve 280 inci maddeler uyarınca suçu bildirme yükümlülügü doğmaz.”

63 Tezcan, Erdem and Önok (n 7) 1257.

${ }^{64}$ Alman CK m 138'de düzenlenen suçta ise farklı bir yaklaşımın sergilendiği görülecektir. Gerçekten, bu suça konu bildirim yükümlülüğünün doğması için bildirilecek suçun planlanmakta olması dahi yeterlidir. Ancak belirtilmelidir ki; bu ayrımın kaynağı Alman CK m 138'in "planlanmakta veya işlenmekte" olan suçların bildirilmemesini suç olarak düzenliyor olmasıdır. TCK m 280 ise yalnızca işlenen suçlara ilişskin bir yükümlülük öngörmüştür. Fischer (n 12) 963.

65 Centel, Zafer and Çakmut (n 17) 457.

66 Tezcan, Erdem and Önok (n 7) 1257.

${ }^{67}$ Benzer bir sınırlama Alman CK m 138'de de mevcuttur. Hükme göre engellenmesi artık mümkün olmayan suçların bildirilmesi yükümlülüğ̈̈ bulunmamaktır. Schönke and Schröder (n 12) 1452.
} 
ermesinin üzerinden uzun bir zaman geçmiş olsa da böyle bir suçun öğrenilmesiyle bildirim yükümlülüğü doğar. $\mathrm{Bu}$ yükümlülüğün mevcut olmayacağı bir halin bildirilecek suç bakımından dava zamanaşımının artık sona ermiş bulunduğu haller olduğu söylenebilir, zira böyle bir durumda suç bildirilse dahi herhangi bir muhakeme işleminin yapılmasına imkan yoktur ve bildirimin yapılmaması TCK m 280'in koruduğu hukuksal değeri herhangi bir şekilde ihlal etmez. Bu nedenle böyle ihtimallerde bildirimin yapılmaması ceza hukuku bakımından önemsiz hareket sayılmalıdır ${ }^{68}$.

\section{b. Suça İlişkin Belirti ile Karşılaşılması}

Bildirim yükümlülüğünün doğması için, sağlık mesleği mensubunun suçun işlendiğini gösteren bir belirti ile karşılaşmış olması gerekmektedir. Madde metninde TCK m 278 ve 279 'dan farklı olarak bir suçun işlendiğini öğrenmekten veya işlenen suçu bildirmekten bahsedilmemesi, belirti ile karşılaşılmasının suçun unsuru olarak düzenlenmiş olması doktrinde unsurun kapsamına ilişkin tartışmalara yol açmıştır. $\mathrm{Bu}$ tartışmaların temelini belirti kavramına verilen anlam oluşturmaktadır.

Doktrinde baskın görüşün belirtiyi bir suçun işlendiğini gösteren maddi iz veya emare olarak yorumladığ 1 görülmektedir ${ }^{69}$. Bu görüşü savunan yazarlar düşüncelerini ceza muhakemesi hukuku literatüründeki delil türleri ayrımına dayandırmışlardır. Gerçekten, ceza muhakemesinde, delillerin belirti, beyan ve belge delilleri olarak üçe ayrıldığ 1 ifade edilmiştir ${ }^{70}$. Belirti delilleri olaydan geriye kalan iz ve eserler ${ }^{71}$, olaydan geriye kalan ve olayın parçası mahiyetindeki gerçeklik parçalar1 ${ }^{72}$ olarak tanımlanmaktadır. Beyan delili suç hakkında doğrudan bilgi veren delil türü ${ }^{73}$, maddi olaya ilişkin açıklamalar ${ }^{74}$ olarak tanımlanmışıtır. Bir açıklamanın beyan delili özelliğini kazanması bunun yetkili makamlar önünde ve usulüne uygun olarak yapılmasına bağlıdır ${ }^{75}$. Bu çerçevede beyan delilleri şüpheli ve sanık ifade ve sorgusu, olaya ilişkin bilgisi olan kişilerin tanıklığı gibi farklı görünümlere sahip olabilir. Son olarak, doktrinde delillerin üçüncü türü olarak gösterilen belge delilleri ise olaya ilişkin bilgiler içeren nesne, olayla ilgili yazılı açıklamalardır ${ }^{76}$. Isşte TCK m 280'de yer alan belirti sözcüğünü ceza muhakemesi anlamında belirti delili biçiminde yorumlayan baskın görüş uyarınca, sağlık mesleği mensubunun bir suçun işlendiğini

\footnotetext{
${ }_{68}$ Kavrama ilişkin bilgi için bkz. Hakan Hakeri, ‘Ceza Hukukunda Önemsiz Hareketler' [2007] Türkiye Barolar Birliği Dergisi 55.

69 Tezcan, Erdem and Önok (n 7) 1257; Zafer (n 8) 1339; Çakmut (n 7) 1053; Yağlıdere (n 7) 67; Gültekin (n 7) 107; Kocasakal (n 21) 190; Koca and Üzülmez (n 10) 949; Meran (n 19) 1341.

70 Veli Özer Özbek and others, Ceza Muhakemesi Hukuku (8th edn, Seçkin Yayıncılık 2016) 688.

71 Nur Centel and Hamide Zafer, Ceza Muhakemesi Hukuku (15th edn, Beta Yayınevi 2018) 240.

72 Fatih Birtek, Ceza Muhakemesinde Delil ve İspat (Adalet Yayınevi 2015) 192.

73 Birtek (n 73) 76; Feridun Yenisey and Ayşe Nuhoğlu, Ceza Muhakemesi Hukuku (6th edn, Seçkin Yayıncılık 2018 ) 492.

74 Centel and Zafer (n 72) 242.

75 Centel and Zafer (n 72) 242.

76 Bahri Öztürk and others, Nazari ve Uygulamalı Ceza Muhakemesi Hukuku (11th edn, Seçkin Yayıncılık 2017) 328; Centel and Zafer (n 72) 290; Ferhat Karabulut, Ersin Karapazarlığlu and Hamza Tosun, 'Ceza Muhakemesinde Delil Kavramı ve Kovuşturma Sürecinde Hakimlerin Delil Algısı’ [2015] Türkiye Barolar Birliği Dergisi 385, 398.
} 
maddi bir iz veya eser aracıllğı̆la öğrenmiş olması gerekmektedir ${ }^{77}$. Buna karşıllık bir suçun işlendiğinin yazılı veya sözlü açıklama ile öğrenilmiş olması, bildirim yükümlülüğünün doğumuna sebebiyet vermeyecektir ${ }^{78}$.

TCK m 280'de yer alan belirti kavramını yalnızca ceza muhakemesi yazınında anlaşıldığı haliyle sınırlı tutmayan kimi yazarlar da mevcuttur. Bu yazarlara göre madde metninde belirti kavramına yer verilmiş olmas1, beyan veya belgeler aracıllğıyla suçun öğrenilmesini suç kapsamı dışına alma amacını taşımamaktadır ${ }^{79}$. Kanun koyucunun suç çerçevesinde belirti, beyan ve belge ayrımını yaptığını söylemek hatalıdır; sağl1k mesleği mensubunun herhangi bir emareye dayalı olarak suç işlendiği kanaatini edinmesi bildirim yükümlülüğünün doğması için yeterlidir ${ }^{80}$.

Kanımca, madde kapsamında belirti kavramını sınırlı biçimde yorumlamak, kanun koyucunun ve suçun amacına aykırı olacaktır. Öncelikle, kanun koyucunun 5237 sayılı TCK ve 5271 sayılı Ceza Muhakemesi Kanunu'nda çeşitli maddelerde delil kavramını farklı sözcüklerle ifade ettiğine dikkat etmek gerekir. Örneğin TCK m 267 'de "maddi eser ve delil", m 271'de "delil veya emare", m 284'te "delil ve eser", CMK m 2'de "eşya veya delil", m 86'da "tıbbi belirti", $m$ 93'te ise "belirti[den]" söz edilmiştir. Bu durumda kanun koyucunun delil, belirti, eser, emare, gibi kavramları birbiriyle benzer anlamlara gelecek şekilde kullandığ 1 yorumunda bulunulabilir.

İkinci olarak, bir açıklamanın beyan delili olarak değerlendirilebilmesi için mahkeme veya diğer adli makamlar önünde yapılmış olması gerektiği tekrarlanmalıdır. $\mathrm{Bu}$ nedenle beyan delili; şüpheli, sanık, mağdur, suçtan zarar gören, tanık veya bilirkişi gibi süjelerin adli makamlara yaptığı ve Ceza Muhakemesi Kanunu'nda yer alan kurallara uygun bir biçimde alınmış olan sözlü açıklamalarıyla sınırlıdır. Buna karşılık, yargılama süreci dışında bir kimsenin diğer bir kişiye yaptığı açıklamalar beyan delili olarak kabul edilmemelidir. Bunlar aslında kişilerin beş duyusuyla algılayabilecekleri dış dünyada gerçekleşmiş olan olaylar olarak nitelendirilebilir. Bu durumda ise öğreti tarafından beyan delili kabul edilen ifadelerden çok belirti delili sayılan emarelere daha yakın görünmektedirler.

Bunun yanında, hastanın veya bir başka kişinin bir suçun faili veya mağduru olduğuna dair açık beyanının bildirim yükümlülüğünü doğurmaması, ancak suç şüphesini uyandırabilecek başka maddi izlerin öğrenilmesinin suçu oluşturması mantığa da aykıııdır. Örneğin bir hekimin hastanın yakın zamanda uyuşturucu kullanmış olduğunu gözlerinin kanlanması veya üzerindeki esrar kokusundan

\footnotetext{
7 Çakmut (n 7) 1053; Bulut (n 7) 87; Gültekin (n 7) 107; Koca and Üzülmez (n 10) 950; Meran (n 19) 1341; Selahattin Kolcu, 'TCK'da Suçu Bildirmeme Suçu' (İstanbul Kültür Üniversitesi 2014) 205-206.

78 Tezcan, Erdem and Önok (n 7) 1257; Zafer (n 8) 1339.

79 Kocasakal (n 21) 193.

80 Ünver, TCK'da Düzenlenen Adliyeye Karşı Suçlar - Ifttira, Suç Uydurma, Suç Üstlenme, Yalan Tanıklık ve Bilirkişilik, İnfaz Kurumlarından Kaçma (n 13) 414. Beyanın da belirti kabul edilmesi gerektiği yönünde bkz. Hakeri (n 7) 1278.
} 
anlaması bildirim yükümlülüğünü doğuracak; ancak dış dünyaya yönelik bir koku veya görsel iz göstermeyen hastanın uyuşturucu kullanıyor olduğunu açıkça ifade etmesi suç kapsamında kabul edilmeyecektir ${ }^{81}$. Bu konuda daha da çarpıcı bir örnek verilebilir: Tedavi ettiği hastanın tırnak altlarında deri kalıntısı bulan bir hekim, bu belirtinin yaralama veya öldürme suçuna işaret ettiği şüphesi dolayısıyla bu kişiyi ve olguyu bildirmekle yükümlüdür. Ancak beyanların bildirim yükümlülügünü doğurmayacağı kabul edilirse şöyle bir olay gerçekleşebilir: Aynı hastanın tırnak altlarında deri kalıntısı bulunmamış olsa; ancak hasta birçok kişiyi öldürmüş ve hala aranmakta olan bir seri katil olduğunu açıkça ikrar etse, öldürdüğü kişilerin isimlerini teker teker saysa ve hatta suçta kullandığı silahı ve kurbanlarının cesetlerini nereye sakladığını hekime açıklasa dahi hekimin bu suçları bildirim yükümlülüğü doğmayacaktır, zira hastanın ifadelerinin hepsi birer beyan niteliğindedir! Böyle bir kabulün doğru olmayacağı ortadadır.

Açıklanan sebeplerle, belirti kavramının henüz muhakeme süreci içerisinde delil niteliğini kazanmamış, bireylerin beş duyularıyla algılayabilecekleri ve suç şüphesi oluşturan herhangi bir emare ve iz olarak anlaşılması uygun olacaktır.

Suç işlendiğini gösteren belirti ile karşılaşılması, bu belirtinin varlığının öğrenilmesi anlamına gelmektedir ${ }^{82}$. Ayrıca, kanunda bu yönde herhangi bir sınırlamanın yapılmamış olmasından hareketle, belirtinin doğrudan sağlık mesleği mensubunun hizmet verdiği kişi üzerinde bulunması veya bu kişiden kaynaklanması da gerekmeyecektir ${ }^{83}$.

\section{c. Belirtiyle Karşılaşmanın Görev Sırasında Gerçekleşmesi}

Sağlı mesleği mensubunun suç işlendiğine yönelik belirti ile karşılaşması, görevini icra ettiği sırada olmalıdır. 765 sayılı mülga Türk Ceza Kanunu’nun ilgili hükmünde yer almayan bu koşul, sağlık mesleği mensubunun her suçu bildirmekle yükümlü kılınmasını engellemektedir.

Sağlık mesleği mensuplarının görevleri 1219 sayılı Tababet ve Şuabatı San'atlarının Tarzı İcrasına Dair Kanun, 6197 sayılı Ezcacılar ve Eczaneler Hakkında Kanun ${ }^{84}$, 6283 sayılı Hemşirelik Kanunu ${ }^{85}$, Tıbbi Deontoloji Nizamnamesi ${ }^{86}$ ve diğer ilgili mevzuatta düzenlenmektedir. Sağllk mesleği mensubunun bu mevzuatta yer alan

\footnotetext{
1 TCK m 191'de yer alan "Kullanmak için uyuşturucu veya uyarıcı madde satın almak, kabul etmek veya bulundurmak ya da uyuşturucu veya uyarıcı madde kullanmak" suçu bakımından TCK m 192/4’teki koşulların oluşması halinde bildirim yükümlülüğünün doğmayacağına dikkat edilmelidir. Bu konuda bilgi için bkz. III.C.1.a. Bir Suçun İşlenmiş Olması.

82 Yağlıdere (n 7) 68. Alman hukukunda ise failin yalnızca suçun varlığını öğrenmesi değil, ikna edici bilgiye sahip olması ("glaubhaft erfährt") aranmıştır. Bkz. Fischer (n 12) 964; Joecks (n 47) 241.

83 Zafer (n 8) 1340.

${ }^{84}$ 18.12.1953 tarihli ve 6197 sayılı Eczacılar ve Eczaneler Hakkında Kanun. Resmi Gazete: 24.12.1953/8591.

85 25.02.1954 tarihli ve 6283 sayılı Hemşirelik Kanunu. Resmi Gazete: 02.03.1954/8647.

${ }^{86}$ 13.1.1960 tarihli Tibbi Deontoloji Nizamnamesi. Resmi Gazete: 19.02.1960/10436.
} 
teşhis, tedavi, ilk yardım, ilaç sunulması gibi sağlık hizmetlerini verdiği sırada bir suçun işlendiği yönünde belirtiyle karşılaşırsa, bu suçu yetkili makamlara bildirmekle yükümlü olacaktır.

Doktrinde de ifade edildiği üzere, "görevi sırasında" kavramı ile kanun koyucunun görevin yapıldığı süreyi mi yoksa öğrenmenin görev ile nedensel bağlantının bulunmasını mı kastettiği açık değildir ${ }^{87}$. Belirtilmelidir ki; bu konuda doktrinde genelde karma bir yaklaşım sergilenmiştir ${ }^{88}$. Sağlık mesleği mensubunun suçu bildirme yükümlülüğünün doğması için öncelikle belirtiyle karş1laşmanın görevin yapıldığı esnada olması gerekir. Bu nedenle örneğin kişinin izinliyken bir suç belirtisi ile karşılaşması TCK m 280 kapsamına girmez. Bunun yanında, belirtiyle karşılaşmanın sağlık hizmetinin verilmesiyle nedensel olması gerektiği de kabul edilmektedir $^{89}$. Buna göre, örneğin bir eczacının mesai saatleri içerisinde eczanesi dışında gerçekleşen bir hırsızlık suçunun tanı̆̆ı olması, eczacılık hizmetinin icrasıyla bağlantılı olarak suçun öğrenilmesi anlamına gelmeyeceğinden, bildirim yükümlülüğünün doğmasına sebep olmayacaktır. İfade edilmesi gereken bir husus, hekimlerin mesai saatleri içerisinde olmayan hallerde acil müdahalede bulunmalarının da görevleri kapsamında olduğudur ${ }^{90}$. Bu konu Tıbbi Deontoloji Nizamnamesi m 3 'te açıkça dile getirilmiştir. Dolayısıyla olağan görevi sırasında olmasa bile, bir hekimin mevzuattan doğan görevini icra etmesi halinde dahi, bu sırada karşılaşılan belirtileri bildirmesi gerekecektir. Bunun yanında, "görevi sırasında" kavramı olağan şartlarda sağlık hizmetinin sunulduğu yer ile de sınırlı bir kavram değildir. Bir aile hekimi veya ebenin poliklinik dişında, hasta evinde sağlık hizmeti veriyor olması durumunda da belirti ile karşılaşılması yeterlidir ${ }^{91}$.

\section{Bildirimin Yükümlülüğünün İhmali}

\section{a. Bildirimin Yetkili Makamlara Yapılması}

TCK m 280 uyarınca sağlık mesleği mensubunun görevi sırasında bir suça ilişkin belirtiyle karşılaşması durumunda, bu konuda yetkili makamlara bildirimde bulunması gerekmektedir. Suçla korunan hukuksal yararın adliye ve suçun düzenlenme amacının adliyenin faaliyetlerinin gerçekleştirilebilmesi ve suçların cezasız kalmaması olduğu düşünüldüğünde, "yetkili makam” kavramının suça ilişkin soruşturmayı başlatmaya yetkili adli makamları işaret ettiği açıktır². Bu makamlar

\footnotetext{
7 Zafer (n 8) 1338.

88 Ünver, TCK'da Düzenlenen Adliyeye Karşı Suçlar - Ifttira, Suç Uydurma, Suç Üstlenme, Yalan Tanıklık ve Bilirkişilik, Infaz Kurumlarından Kaçma (n 13) 406.

89 Tezcan, Erdem and Önok (n 7) 1258; Bulut (n 7) 86; Üzülmez (n 10) 828; İzzet Özgenç, 'Sağlık Mesleği Mensuplarının Suçu Bildirme Yükümlülüğünün Kapsam ve Sınırları' (Sağllk Düşüncesi ve Tıp Kültürü Platformu, 2008) <http://www. sdplatform.com/Dergi/169/Saglik-meslegi-mensuplarinin-sucu-bildirme-yukumlulugunun-kapsam-ve-sinirlari.aspx $>$ accessed 24 September 2019.

90 İplikçi (n 7) 91; Koca and Üzülmez (n 10) 948.

91 Kocasakal (n 21) 200; Koca and Üzülmez (n 10) 947; Üzülmez (n 10) 829.

92 Bulut (n 7) 88; Gültekin (n 7) 108; İplikçi (n 7) 88; Ünver, TCK'da Düzenlenen Adliyeye Karşı Suçlar - Iftira, Suç Uydurma,
} 
CMK m 158'de açıkça belirlenmiştir. Buna göre bildirimin Cumhuriyet Başsavcılığ 1 veya kolluk makamlarına (CMK m 158/1), valilik, kaymakamlık veya mahkemeye (CMK m 158/2), yurtdışında işlenen ve ülkede takibi gereken suçlar hakkında Türkiye'nin elçilik veya konsolosluklarına (CMK m 158/3) veya kamu görevinin yürütülmesiyle bağlantılı olarak işlendiği iddia edilen bir suç nedeniyle ilgili kurum veya kuruluş idaresine (CMK m 158/4) yapılması mümkündür.

Doktrinde yetkili makamların yukarıda belirtilen kurum ve mercileri içerdiği yönünde pek tartışma bulunmasa da özellikle kamu görevlisi sağlık mesleği mensuplarının kendi şef, amir veya müdürlerine bildirim yapmasının bildirim yükümlülügünü yerine getirilmesi için yeterli olup olmadığı hususunda farklı görüşler

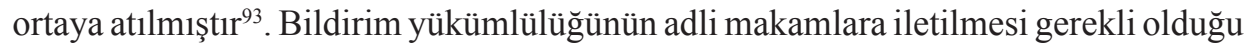
için, kamu görevlisinin kendi amirlerine bildiriminin yükümlülüğü yerine getirmek kabul edilemeyeceğini söylemek gerekecektir ${ }^{94}$. Zira kamu görevlisinin amiri suçların takibinde yetkili makam değildir. Amire bildirim; ancak yukarıda belirtilen ve CMK m 158/4'te yer alan koşullar gerçekleştiyse bildirim yükümlülüğünün yerine getirilmesi sayılır. Bunun için de bildirilmesi gereken suçun hem kamu görevinin yürütülmesiyle bağlantılı olması, hem de sağl1k mesleği mensubunun kendi çalıştı̆̆1 kurum ile ilgili olmas1 gerekecektir ${ }^{95}$.

Benzer bir tartışma özel sektörde çalışan sağlık mesleği mensupları açısından ortaya çıkmıştır. Doktrinde kimi yazarlar özel sektörde çalışan sağlık mesleği mensuplarının bildirimlerini sorumlu müdürlerine yapmalarının yeterli olacağını öne sürmekteyse $\mathrm{de}^{96}$ bu görüşün hatalı olduğu kanaatindeyim. Madde düzenlemesinde bildirimin yetkili makamlara yapılması gerektiği açıkça ifade edilmiştir. Özel sektörde çalışan bir kişi, sağlık mesleği mensubunun müdürü olsa dahi suçların takibi bakımından bir yetkiye sahip olmayan bir üçüncü kişidir. Bildirimin bu kişiye yapılması, suçun amacını gerçekleştirmeye herhangi bir katkı sağlamadığı gibi, adliyenin suçun veya belirtinin haberdar olmasına da sebep olmayacaktır. Bu nedenle, bildirimin özel kişilere yapılması yükümlülüğün yerine getirilmesi olarak kabul edilmemelidir ${ }^{97}$.

Sağlık mesleği mensubunun bildirimi ilettiği kişinin yetkili makam olduğu düşüncesine sahip olması ise yanılma kurumunu ilgilendirmektedir ${ }^{98}$.

Suç Üstlenme, Yalan Tanıklık ve Bilirkişilik, Infaz Kurumlarından Kaçma (n 13) 418; Kocasakal (n 21) 206; Koca and Üzülmez (n 10) 952; Zafer (n 8) 1344; Çakmut (n 7) 1054-1055; Yağlıdere (n 7) 69; Hakeri (n 7) 1276. TCK m 278'de yer alan suçtaki aynı kavramın adli makamları işaret ettiğine ilişkin bkz. Tezcan, Erdem and Önok (n 7) 1251-1252; Erdem (n 11) 116; Döner (n 37) 80-81.

93 Gültekin (n 7) 108; Kocasakal (n 21) 206; Koca and Üzülmez (n 10) 952.

94 Yağlıdere (n 7) 69.

95 Aynı yönde bkz. Ünver, ‘TCK'da Sağlık Personelinin Ceza Hukuku Sorumluluğuna Yol Açabilecek Hükümler' (n 13$) 107$.

96 Gültekin (n 7) 108; Bulut (n 7) 88.

97 Zafer (n 8) 1344.

98 Bu konudaki açıklamalar için bkz. IV. Tipikliğin Sübjektif (Manevi) Unsurları. 


\section{b. Bildirmemek veya Bildirimde Gecikme Göstermek}

Yükümlülüğün doğması, yani sağl1k meslek mensubunun görev sırasında bir suç işlendiğine ilişkin belirtiyle karşılaşması üzerine yetkili makamlara bu hususta bildirim yapılmas1 gerekmektedir. Bildirimin ihmali veya bildirimde gecikilmesi TCK m 280'in fiil unsurunu oluşturur. Bu açıdan suç seçimlik hareketlidir.

Bildirim yetkili makamların bir suçun işlendiği hususunda bilgilendirilmesidir ${ }^{99}$. Bu konuda CMK m 158'de yer alan suçun ihbarına ilişkin kuralların uygulanması uygundur. Buna göre bildirimin yazılı veya sözlü olarak yapılması mümkündür. Doktrinde ileri sürüldügü üzere, bildirimin telefon, işaret veya başka türlü icrai hareketlerle yapılmas1, isim vererek veya anonim olarak da yapılması yeterlidir; önemli olan yetkili makamların suçun işlendiğinden ve sağlık mesleği mensubunun bu konuda öğrendiği hususlardan haberdar edilmesidir ${ }^{100}$.

Doktrinde üzerinde tartışılan bir konu, yapılması gereken bildirimin kapsamıdır. Bazı yazarlar sağlık mesleği mensubunun suçu bildirirken bir suçun unsurunu oluşturan tipik fiilin gerçekleştiği şüphesinin iletilmesinin yeterli olacağı görüşündeyken ${ }^{101}$, kimi yazarlar bunun yeterli olmadığını, ayrıca sağlık mesleği mensubunun ulaştığı fail, mağdur ve fiilin işlenişine dair bilgi ve tıbbi değerlendirmeleri de bildirimin içerisinde bulunması gerektiğini belirtmektedirler ${ }^{102}$. Bu kapsamda tıbbi değerlendirmeler hasta üzerinde bir belirtinin bildirilmesi söz konusu olduğunda önem taşıyacaktır. Bu değerlendirmeler belirti teşkil eden unsurun, örneğin bir yaralanmanın mahiyeti, nasıl bir fiil sonucu gerçekleşmiş olduğuna işaret ettiği gibi tıp bilimi çerçevesinde olguların gerçekleşme biçimine dair sağlık mesleği mensubunun bilimsel görüşünü ifade eder. $\mathrm{Bu}$ konudaki tartışmanın sebebinin suçun düzenlenme amacına dair olduğu söylenebilir. Eğer suçun düzenleniş amacının yalnızca adli makamların bir suçun işlendiğinden haberdar olmaları olduğu kabul edilirse bildirimin şüpheyle sınırlı olması yeterli görülecektir. Diğer yandan, suçun düzenleniş amacının bu eserde de savunulduğu gibi soruşturma ve kovuşturmanın mümkün olan en etkili şekilde yapılması, adli makamların suça ilişkin delil teşkil edebilecek belirti ve emarelerden haberdar edilmesi olduğu ve suçla korunan hukuksal değerin devletin etkili soruşturma yükümlülüğü çerçevesinde adli fonksiyonların etkililiği olduğu söylenirse aksi bir sonuca varmak gerekecektir. Gerçekten, örneğin yetkili makamların bilgi sahibi olmadığı bir suçun işlendiğine dair belirtiyle karşılaşan sağlik mesleği mensubunun elindeki belirtinin elde ediliş biçimi, fiil, fail ve mağdura ilişkin bilgiler başlatılacak soruşturmanın başlangıç dayanağını oluşturacaktır. Bu bilgilerin adli mercilere iletilmemesi durumunda

\footnotetext{
99 Koca and Üzülmez (n 10) 952.

100 Koca and Üzülmez (n 10) 952. Anonim olarak yapılan ve tutanağa sağlı mesleği mensubu tarafindan yapıldığı geçirilmeyen bildirim suçun oluşmasını engelleyecekse de ispat bakımından sıkıntılara yol açabilecektir. Aynı yönde bkz. Yener Ünver, 'Hekimin Cezai Sorumluluğu', Roche Sağllk Hukuku Günleri (Roche Müstehzarları Sanayi 2007) 171.

101 Döner (n 37) 78; Bulut (n 7) 89.

102 Zafer (n 8) 1344; Gültekin (n 7) 108; Ünver, TCK'da Düzenlenen Adliyeye Karşı Suçlar - Ifttira, Suç Uydurma, Suç Üstlenme, Yalan Tanıklık ve Bilirkişilik, İnfaz Kurumlarından Kaçma (n 13) 420.
} 
soruşturmayı başlatacak savcı yalnızca bir suçun işlendiğine dair veriye sahip olacaktır. $\mathrm{Bu}$ denli sınırlı bir bilginin de suç soruşturması bakımından faydalı olmadığını kabul etmek gerekir. Bu sebeple, sağlık mesleği mensubunun yapacağı bildirim, karşılaşılan belirtiyle bağlantılı olarak elde edilen tüm bilgileri kapsamalıdır. Aksi takdirde bildirim yükümlülüğünün tümüyle yerine getirildiği söylenemeyecektir.

Sağlık mesleği mensubunun bildirim yükümlülüğünü yerine getirmesine ilişkin bir diğer tartışmalı husus, yükümlülüğün yetkili makamların önceden haberdar olduğu bir suça ilişkin belirtiyle karşılaşılması veya belirtiyle karşılaşılan birden fazla sağlık mesleği mensubundan birinin bildirimde bulunmuş olması hallerinde devam edip etmeyeceğidir. Her iki durumda da yetkili makamlar bildirimin yapılmasından önce belirtisiyle karşılaşılan suçun işlendiğine dair bilgi sahibidir. Doktrinde yetkili makamların konu hakkında bilgi sahibi olduğu halde bildirim yükümlülüğünün ortadan kalktığ1 görüşünü savunanlar olduğu gibi ${ }^{103}$, aksi yönde görüş sunanlar da mevcuttur ${ }^{104}$. Bu konuda da suçun düzenleniş amacı ve suçla korunan hukuksal değerle bağlantılı bir yorum yapmak gerekmektedir. TCK m 280 kanımca adli makamların fonksiyonlarının etkililiğini korumakta ve suça ilişkin yargılamanın etkili bir biçimde yapılmasını amaçlamakta olduğu için, sağlık mesleği mensubunun yetkili makamların haberdar olduğu suçla ilgili ek ve önemli bir bilgiye sahip olması durumunda bu bilgiyi iletmesi gerekmektedir. Yani sağlık mesleği mensubunun bildirim yükümlülüğü, yalnızca yetkili makamların suçun işlendiği konusunda bilgi sahibi olması nedeniyle sona ermeyecektir ${ }^{105}$. Buna karşılık, sağl1k mesleği mensubunun elindeki belirti yargılamanın etkililiği bakımından hiçbir önem taşımıyorsa ve bildirimin yapılmaması suçun koruduğu hukuksal değere yönelik tehlike teşkil etmiyorsa, bildirimin yapılmamasının ceza hukuku bakımından önem arz edecek haksızlık muhtevasına sahip olmadığını söylemek mümkündür. Buna göre, aynı belirtiyle karşılaşan bir sağlık mesleği mensubunun bildirimi, diğerlerinin bildirimde bulunmasını gereksiz kılacaktır. Ancak belirtiyle karşılaşan sağlık mesleği mensuplarının biri, örneğin özel uzmanlığı nedeniyle soruşturmaya yardımcı olacak ek bir tıbbi değerlendirme yaptıysa, bu değerlendirme sonuçlarının da yetkili makamlarla paylaşılması gerekecektir.

Suçun fiil unsuru bildirimin yukarıda belirtilen biçimde hiç yapılmamasını kapsadığı gibi, bu bildirimin geç yapılmasını da içermektedir. Buna göre, sağlık mesleği mensubu bir suçun işlendiğine ilişkin karşılaştığı belirtiye dair bilgisini

\footnotetext{
103 Tezcan, Erdem and Önok (n 7) 1251-1252; Erdem (n 11) 115.

104 Ünver, 'TCK'da Sağlık Personelinin Ceza Hukuku Sorumluluğuna Yol Açabilecek Hükümler' (n 13) 107. Yazar madde metninde bildirilmiş ve bildirilmemiş suçlara ilişkin bir ayrımın olmadığını ve bildirimi yapmakla yükümlü sağlık mesleği mensubunun yetkili makamların suça ilişkin bilgi sahibi olup olmadıklarını bilemeyeceğini, ayrıca her failin bildirim yükümlülüğünün birbirinden tümüyle bağımsız olduğunu belirtmektedir.

${ }_{105}$ Aynı yönde bkz. Ünver, TCK'da Düzenlenen Adliyeye Karşı Suçlar - Ifttira, Suç Uydurma, Suç Üstlenme, Yalan Tanıklık ve Bilirkişilik, İfaz Kurumlarından Kaçma (n 13) 420. Ancak yazar belirti hakkında sahip olunan bilginin adli soruşturma bakımından önemine ilişkin bir ayrım gözetmemiştir.
} 
yetkili makamlarla paylaşsa dahi, bu bildirim gecikmiş olursa suç oluşacaktır. Bu noktada bildirimin hangi anda gecikmiş sayılacağını belirlemek oldukça önemlidir. Doktrinde yazarlar genellikle bu konuda soyut bir belirlemenin yapılmasını mümkün görmemekte ve doğru yöntemin TCK m 280'e dair yargılamayı yapacak mahkemenin gecikme olup olmadığını somut olayın koşullarına göre belirlemesi olduğunu ifade etmektedir ${ }^{106}$. Gecikme için aranacak makul sürenin yine hâkim tarafindan belirleneceği, ancak bu konuda kanunda azami bir sürenin öngörülmüş olması gerektiği de ifade edilmiş̧iir ${ }^{107}$. Gerçekten kanunda gecikme için kesin bir süre sınırının öngörülmemiş olması nedeniyle aranacak sürenin belirlenmesi mahkeme tarafından somut olayın özellikleri ışı̆ında yapılacaktır. Böyle bir düzenlemenin, her olayın kendi özelliklerinin oldukça farklı olabileceği düşünüldüğünde soyut bir süre sınırından daha doğru olduğu belirtilmelidir. Yine de, mahkemenin değerlendirilmesinde dikkat edilmesi gereken husus, sürenin öncelikle suçun düzenlenme amacı ışı̆̆ında ortaya konmas1 gerektiğidir ${ }^{108}$. Gecikmenin gerçekleşme an1, bildirim yükümlülüğünün ihdasının artık anlamsız kaldığı, yani yapılacak bildirimin soruşturma ve kovuşturma bakımından önemini kaybettiği, yargılama faaliyetinin bildirimin yapılmasındaki gecikme nedeniyle önemli ölçüde zorlaştı̆̆ andır $^{109}$. Buna göre, bildirimin yapılması için örneğin bir gün beklenmesi, bildirim konusu suçun takibi için herhangi bir sorun oluşturmuyorsa gecikmenin gerçekleştiğini söylemek mümkün değildir. Buna karşılık eğer sağlık mesleği mensubunun bildirimi suçun delillerinin ortadan kaldırılmasına yol açacak denli bir süre geciktiyse artık bildirim yapılsa dahi gecikmiş kabul edilmelidir.

Son olarak, doktrinde bildirimin yapılması gereken ana ilişkin önemli bir tartışmanın sağlık mesleği mensubunun önce tedaviyi gerçekleştirmesi sebebiyle bildirimi geciktirmesi hususunda olduğu görülmektedir. Kanımca bu konudaki değerlendirmede genel kuraldan ayrılmayı gerektirecek bir durum yoktur. Eğer suçun takibi açısından tehlike yaratan bir durum yoksa, bildirimden önce tedavinin yapılmış olması tek başına bildirimin geç yapılmış olması anlamına gelmeyecektir. Buna karşı1ık tedavi sebebiyle bildirimin yapılması gecikmiş ve bundan dolayı suçun takibi önemli ölçüde zorlaşmış ise, bu halde TCK m 280 çerçevesinde bildirim geç yapılmış sayılır. Ancak böyle bir durumda tedavi yapılmasının zorunluluk haline ilişkin kurallar çerçevesinde incelenmesi ve sağllk mesleği mensubuna ceza verilmemesi mümkündür.

\footnotetext{
106 Yavuz Erdoğan, 'Sağlık Mesleği Mensuplarının Suçu Bildirmeme Suçu' [2009] Legal Hukuk Dergisi 1103, 1107; Tezcan, Erdem and Önok (n 7) 1258; Çakmut (n 7) 1055; Yağlıdere (n 7) 69; Bulut (n 7) 89; Zafer (n 8) 1343; İplikçi (n 7) 93-94; Kocasakal (n 21); Koca and Üzülmez (n 10) 951; Arslan and Azizağaoğlu (n 7) 1124; Meran (n 19) 1341.

107 Ünver, TCK'da Düzenlenen Adliyeye Karşı Suçlar - Iftira, Suç Uydurma, Suç Üstlenme, Yalan Tanıklık ve Bilirkişilik, İnfaz Kurumlarından Kaçma (n 13) 402.

108 Suçun koruduğu hukuksal değer ışığında yorum yapılmasının doğru olacağı görüşüne Alman doktrinin yorumu 1şığında da ulaşmak mümkündür. Alman CK m 138'in suçların önlenmesi amacına yönelik olduğu gerekçesiyle geç bildirimin suçun önlenmesinin artık mümkün olmayacağı andan itibaren yapılan bildirimi ifade ettiği ileri sürülmüştür. Türk hukukunda da suçların etkili bir biçimde takibinin korunduğu kabul edilirse geç bildirimin artık bu amacın yerine getirilmesinin mümkün olmadığı zaman olduğunu söylemek gerekecektir. Bkz. Schönke and Schröder (n 12) 1453.

109 Aynı yönde bkz. Tezcan, Erdem and Önok (n 7) 1258; Bulut (n 7) 89.
} 


\section{Tipikliğin Sübjektif (Manevi) Unsurları}

TCK m 280, kasten işlenebilen bir suçtur ${ }^{110}$. Suçun oluşmasında failin saiki önem taşımaz. Doktrinde kimi yazarlar suçun yalnızca doğrudan kastla işlenebileceğini belirtmekte ${ }^{111}$, yani sağl1k meslek mensubunun karşılaştı̆̆ belirtinin bir suça ilişkin olduğunu bilmesini ve bildirmemek veya geç bildirmeyi istemesini aramaktaysa da, kanımca suçun olası kastla işlenmesi için bir engel bulunmamaktadır ${ }^{12}$. Olası kast, suçun objektif unsurlarının gerçekleştiğinin öngörülmesi ve bu halin kabullenilmesi, duruma kayıtsız kalınması, razı olunması hallerinde bulunur ${ }^{113}$. Hatta denilebilir ki; TCK m 280'in gerçekleşmesinde failin olası kastıyla karşılaşılması ihtimali, doğrudan kastın oluşmasından çok daha yüksektir. Ancak hastanın açık beyanının veya belirtinin bir suçun işlendiğini kesin olarak göstermesi gibi hallerde, yani sağlik mesleği mensubunun bir suça ilişkin belirtiyle karşılaş̧ı̆̆ını bildiği ve buna rağmen kasıtlı olarak bildirimi yapmadığı durumlarda doğrudan kasttan söz edilebilir. Fakat, örneğin bir hekimin hastasının vücudunda gördüğü bir morluğun yaralama suçuyla bağlantılı olduğundan emin olamadığı, ancak böyle bir durumu öngördüğü; yine de bu duruma kayıtsız kalmak suretiyle suçu bildirmediği hallerde TCK m 280'in olası kastla işlendiği söylenmelidir ${ }^{114}$.

Suçun taksirli hali kanunda düzenlenmediği için TCK m 280'in taksirle işlenmesine imkân bulunmamaktadır ${ }^{115}$.

Failin kastı, suçun tüm objektif unsurlarını kapsamalıdır ${ }^{116}$. Buna göre, fail sağlık mesleği mensubu olduğunu, görevi sırasında bir belirtiyle karşılaştığını, bu belirtinin bir suça ilişkin olduğunu, belirtiyi yetkili makamlara bildirmediğini veya bildirimde geciktiğini bilmelidir ${ }^{117}$. Ancak failin hukuki detayları bilmesine, örneğin sağlık meslek mensubu kavramının hukuk düzeninde tam olarak neyi ifade ettiğini bilmesine gerek yoktur ${ }^{118}$.

Üzerinde düşünülmesi gereken bir husus, sağlık mesleği mensubunun bildirimde gecikme bakımından kastı olmasının ne anlama geldiğidir. Bildirimin gecikmesi,

\footnotetext{
110 Tezcan, Erdem and Önok (n 7) 1259; Zafer (n 8) 1345; Çakmut (n 7) 1056; Yağlıdere (n 7) 70; Bulut (n 7) 90; Koca and Üzülmez (n 10) 953; Ünver, TCK'da Düzenlenen Adliyeye Karşı Suçlar - Iftira, Suç Uydurma, Suç Üstlenme, Yalan Tanıklık ve Bilirkişilik, İnfaz Kurumlarından Kaçma (n 13) 426.

111 Koca and Üzülmez (n 10) 953; Meran (n 19) 1341; Kocasakal (n 21) 218. Ayrıca bkz. Özgenç, 'Sağlik Mesleği Mensuplarının Suçu Bildirme Yükümlülüğünün Kapsam ve Sınırları' (n 90). Yazar suçun doğrudan kastla işlenebileceği düşüncesine gerekçe olarak madde gerekçesinde sağlı mesleği mensuplarının suçu öğrenmiş olmalarının aranmasını göstermektedir.

112 Aynı yönde bkz. Yağlıdere (n 7) 70; Ünver, TCK'da Düzenlenen Adliyeye Karşı Suçlar - Iftira, Suç Uydurma, Suç Üstlenme, Yalan Tanıklık ve Bilirkişilik, Infaz Kurumlarından Kaçma (n 13) 426; Tezcan, Erdem and Önok (n 7) 1259.

113 Akbulut (n 60) 399; Özgenç, Türk Ceza Hukuku Genel Hükümler (n 60) 250; Artuk and Gökcen (n 18) 331.

114 Krş. Kocasakal (n 21) 218.

115 Tezcan, Erdem and Önok (n 7) 1259.

116 Centel, Zafer and Çakmut (n 17) 365.

117 Tezcan, Erdem and Önok (n 7) 1259.

118 Mahmut Gökpınar, 'Ceza Sorumluluğunun Temeli: “Kast”' [2008] Türkiye Barolar Birliği Dergisi 198, 202; İzzet Özgenç, ‘Kast-Taksir Kombinasyonları’ (1998) 6 Selçuk Üniversitesi Hukuk Fakültesi Dergisi 345, 347.
} 
açıklandığı üzere artık bildirime rağmen etkin bir soruşturma yapılamayacağı, bildirimin anlamsızlaştı̆̆ andır $^{119}$. Sağlık mesleği mensubunun kasten bildirimde geciktiğini söyleyebilmek için bu durumu, yani bu andan itibaren yapacağı bildirimin soruşturmaya yardımcı olmayacağını, bilmesi gerekecektir. Sağlık mesleği mensubunun bildirimde bulunmak için suçun üzerinden birkaç yıl geçmesini beklemesi gibi hallerde kastın varlı̆̆ ortaya konabilecekken, gerçek hayatta yaşanacak birçok olayda sağlik mesleği mensubunun bildirimde gecikmeye ilişkin doğrudan kastının bulunduğunu tespit zor olacaktır. Bu durumlarda TCK m 280'in olası kastla işlendiğinin söylenmesi duruma göre mümkün olabilecektir. Fakat, suç bakımından gecikmenin bulunduğu, ancak gecikme kastının olmadığı haller de sıklıkla görülecektir.

Failin kastının tüm objektif unsurları kapsaması suçun oluşması için gerekli olduğundan, bu unsurların herhangi birindeki yanılma failin kastını kaldıracaktır ${ }^{120}$. Buna göre, örneğin karşılaştığ 1 yaranın bir belirti olduğunu bilmeyen hekim TCK m 280 faili değildir ${ }^{121}$. Aynı şekilde, bildirimini yetkili olmayan bir makama yaptığını bilmeyen sağlık meslek mensubunun da suç kastı olduğu söylenemeyecektir ${ }^{122}$.

Uygulamada karşılaş1labilecek bir sorun, sağlik meslek mensubunun belirtiyle karşılaştığını ve bu belirtinin bir başkası tarafından gerçekleştirildiğini anlamasına rağmen bu fiilin hukukumuzda suç olarak düzenlendiğini bilmemesi sebebiyle bildirimde bulunmaması halidir. Bu konuda doktrinde kimi yazarların TCK $\mathrm{m}$ 30/4'ün ${ }^{123}$ uygulanmasını teklif ettiği görülmektedirr ${ }^{124}$. Yazarlar, sağlik mesleği mensubunun belirtisiyle karşılaştığ 1 fiilin suç olmaktan çıkarıldığ 1 veya affedildiği düşüncesinde olması bunun haksızlık yanılgısı teşkil ettiği görüşündedirler. Kanımca burada sağlık mesleği mensubunun kendi yaptığı hareketin toplumsal düzende antisosyal, haksızlık oluşturmayan bir fiil olduğunu düşündüğünü söylemek mümkün değildir. $\mathrm{Bu}$ somut örnekte mevcut olan durum, sağllk meslek mensubunun karşılaştı̆̆ 1 şeyin bir suç belirtisi olduğunu bilmemesinden ibarettir. Bu durumda fail suçun objektif unsurların birinin gerçekleştiğini bilmemektedir ve suçun tüm objektif unsurlarının oluştuğunu bilmeyen kişinin kastı mevcut değildir.

\section{Hukuka Aykırılığı Kaldıran Haller}

TCK m 280 bakımından Türk Ceza Kanunu'nun genel hükümlerinde yer alan hukuka uygunluk nedenleri yerine göre uygulanabilecektir. Uygulamada sağlık mesleği mensupları açısından tartışma konusu olabilecek haller susma hakkı, sır

\footnotetext{
119 Bu konudaki açıklamalar için bkz. III.C.2.b. Bildirmemek veya Bildirimde Gecikme Göstermek.

120 Schönke and Schröder (n 12) 1455; Joecks (n 47) 243

121 Koca and Üzülmez (n 10) 953.

122 Karşı yönde bkz. Zafer (n 8) 1347. Yazar bildirim yapılan kişinin ihbarı kabule yetkili olmadığının bilinmemesi halini hukuki hata olarak nitelendirmektedir.

1235237 sayılı TCK m 30/4: "İşlediği fiilin haksızlık oluşturduğu hususunda kaçınılmaz bir hataya düşen kişi, cezalandırılmaz."

124 Zafer (n 8) 1347.
} 
saklama yükümlülüğü ve bununla bağlantılı olarak tanıklıktan çekinme hakkı ve mağdurun rızasıdır.

\section{A. Susma Hakkı}

Anayasa m 38/5 uyarınca "hiç kimse kendisini ve kanunda gösterilen yakınlarını suçlayan bir beyanda bulunmaya veya bu yolda delil göstermeye zorlanamaz". Kişinin kendisi veya yakını aleyhine delil göstermeye zorlanamama hakkı, sağlık mesleği mensupları bakımından da uygulama alanı bulacaktır. Anayasa'nın ilgili hükmünün, normlar hiyerarşisindeki üstün yeri de düşünüldüğünde doğrudan uygulanabilir bir düzenleme olduğunu söylemek gerekir ${ }^{125}$. Buna göre, sağlık mesleği mensubunun görevi sırasında karşılaştığ 1 belirtiyi bildirmesi kendisi veya yakınlar1 ${ }^{126}$ bakımından suçlayıcı beyan teşkil edecekse, suçun bildirilmemesi hukuka uygundur ${ }^{127}$. TCK m 280'de böyle bir açık düzenleme mevcut olmaması bu sonuca varılmasına engel değildir, zira TCK m 26/1 uyarınca ${ }^{128}$ kişilerin kendilerine tanınan hakkı icra etmeleri bir hukuka uygunluk nedenidir ${ }^{129}$. Buna karşılık, kimi yazarların da ifade ettiği üzere TCK m 280'de Anayasa m 38/5'e uygun bir düzenlemenin yapılması uygulamada yaşanabilecek sorunları önleyecektir ${ }^{130}$. Bunun yanında AYM'nin TCK m 278'e ilişkin verdiği kararında da Anayasa m 38/5'e uygun bir hukuka uygunluk nedeni tanınmamasını iptal sebebi olarak gördüğünü hatırlatmak gerekir ${ }^{131}$. Mahkeme susma hakkının suçu bildirme yükümlülüğ̈̈ne istisna olarak tanınmamış olmasını hukuka aykırı bulmuş ve TCK m 278 'in bu hak ile uyumlu bir biçimde tekrar düzeltilmesini istemiştir. Bu durum, TCK m 280 'de de benzer bir düzenleme yapılması gerekliliğini güçlendirmektedir.

\section{B. Sır Saklama Yükümlülüğü}

Sağlık mesleği mensupları, meslekleri gereği hastaları tarafindan kendileriyle paylaşılan veya teşhis sonucu elde ettikleri bilgileri başkalarıyla paylaşmama

125 Çakmut (n 7) 1056; Bulut (n 7) 90; Ünver, TCK'da Düzenlenen Adliyeye Karşı Suçlar - Iftitira, Suç Uydurma, Suç Üstlenme, Yalan Tanıklık ve Bilirkişilik, Infaz Kurumlarından Kaçma (n 13) 427; Koca and Üzülmez (n 10) 954.

126 Hak kapsamındaki yakın kavramı doktrinde CMK m 45 çerçevesinde yorumlanmaktadır. Bkz. Yağlıdere (n 7) 73; Zafer (n 8) 1346. Buna göre hak kapsamındaki yakınlar nişanlı, evlilik bağı kalmasa bile eş, kan veya kayın hısımlığından üstsoy veya altsoy, üçüncü derece dahil kan ve ikinci derece dahil kayın hısmı ile evlatlık bağı bulunan kişilerdir.

127 Kaldı ki; kişinin kendi işlediği veya işlenmesine iştirak ettiği suçu yetkili makamlara bildirmesinin beklenmesi mümkün değildir. Bu durumda bildirim yükümlülüğü cezalandırılamayan sonraki hareket olarak kabul edilecektir. Aynı yönde bkz. Schönke and Schröder (n 12) 1454.

1285237 sayılı TCK m 26/1: "Hakkını kullanan kimseye ceza verilmez."

129 Aynı yönde bkz. Yağlıdere (n 7) 73; Kocasakal (n 21) 185.

130 Zafer (n 8) 1346; Ünver, 'TCK'da Sağlık Personelinin Ceza Hukuku Sorumluluğuna Yol Açabilecek Hükümler' (n 13 ) 106.

131 AYM, E. 2010/52, K. 2011/113, 30.06.2011. Kararın ilgili kısmı şu şekildedir: "Anayasanın 38. maddesinde suç ve cezalara ilişskin temel ilkelere yer verilmiştir. Bunlardan biri de maddenin beşinci fikrasında "Hiç kimse kendisini ve kanunda gösterilen yakınlarını suçlayan bir beyanda bulunmaya veya bu yolda delil göstermeye zorlanamaz." biçiminde ifade edilmiştir. Aynı zamanda evrensel bir ceza hukuku ilkesi olan bu anayasal hüküm karşısında yasa koyucu, kişinin kendisini ve yasada gösterilecek belli derecedeki yakınlarını suçlayıcı bir beyanda bulunmaya zorlayan bir düzenleme yapamaz. İtiraz konusu kuralda, işlenmekte olan veya işlenmiş olmakla birlikte sebebiyet verdiği neticelerin sınırlandırılması halen mümkün bulunan bir suçu yetkililere bildirmeyenlerin maddede öngörüldüğü biçimde cezalandırılacakları belirtilirken, gerek maddede, gerekse bu maddeye atıf yapacak biçimde başka bir yerde, bu suçun fail veya failleriyle anılan suçu bildirmeyen kişi arasındaki yakın akrabalık durumu cezasızlık açısından ayrık tutulmamıştır. Açıklanan nedenle kural Anayasa'nın 38. maddesine aykırıdır. İptali gerekir." 
yükümlülüğü altındadır. Hekimin sır saklama yükümlülüğü olarak bilinen bu ödev, uluslararası belgelerin yanında hukukumuzda Hasta Hakları Yönetmeliği m 20-23'te ve Türk Tabipler Birliği tarafından düzenlenen Hekimlik Meslek Etik Kuralları m 9'da yer almaktadır. Hekimin hastasına ilişkin sırrı başkalarıyla paylaşması, Hasta Hakları Yönetmeliği m 23 uyarınca ancak "kanun ile müsaade edilen haller[de]" mümkündür. Böyle bir halin mevcut olmaması durumunda sırrın paylaşılması, TCK m 136'da düzenlenen "Verileri hukuka aykırı olarak verme veya ele geçirme" suçunu oluşturacaktır. Ancak TCK m 280 düzenlemesi, sırrın paylaşılmasına kanunun müsaade ettiği hallerden birini oluşturmaktadır.

Doktrinde de belirtildiği üzere, kanun koyucu TCK m 280 düzenlemesini yaptığ1 sırada sır saklama yükümlülüğüne istisna bir hal oluşturmuştur ${ }^{132}$. Bu sebeple suça ilişkin bir belirtinin öğrenilmesi durumunda bunun yetkili makamlarla paylaşılmas1, TCK m 136'da düzenlenen suçu oluşturmamaktadır ${ }^{133}$. Görülmektedir ki; sır saklama yükümlülüğü TCK m 280 bakımından bir hukuka uygunluk nedeni oluşturmamakta, tam tersine TCK m 280 düzenlemesi sır saklama yükümlülüğünün ihlalini hukuka uygun hale getirmektedir ${ }^{134}$. Ancak belirtilmelidir ki; sır saklama yükümlülüğünün suçu bildirme yükümlülüğüne göre daha düşük önemde olduğunun kanun koyucu tarafından kabulü eleştirilebilir bir durumdur. Yapılan bu düzenleme hastaların örneğin bir suç faili oldukları ve suçun adli makamlarca öğrenilmesini istemedikleri hallerde tedavi ile özgürlük arasında bir seçim yapmaları zorunluluğunu doğurmaktadır. Hatta tercih durumu kişinin örneğin şikayete bağlı bir suçun mağduru olduğu hallerde daha belirgin biçimde yaşanacaktır. Kişinin kendisinin dahi gizli kalması ve soruşturulmasını istemediği bir suçun onu tedavi eden hekim tarafından adli makamlara bildirmesi gerekecektir. Böyle durumlarda hastaların tedavi yerine gizliliği seçmeleri olasıdır. Suçların takibi hukuk düzeninde önem taşıyan bir amaç olsa da kişilerin sağlık hakkının bu amaç uğruna feda edilmesi kabul edilebilir değildir. 765 sayılı mülga TCK m 530'da suçun "yardım ettikleri kimseyi takibata maruz kılacak ahval müstesna" haller ile sınırlı tutulmuş olması ve en azından suç faili olan hastaların böyle bir seçime zorlanmamış olduğunu ifade etmek gerekir. Fakat bu imkanın suç mağduru hastalar bakımından da öngörülmesi daha doğru olurdu. Alman CK'da m 139 ile çeşitli sağlık meslek mensuplarının bildirim yükümlülüğüne, belirli şartlar çerçevesinde tabi olmadıkları açıkça belirtilmiştir ${ }^{135}$. Bu durum karşısında neden 5237 sayılı Türk Ceza Kanunu'nda tedavi olan kişilerin özel hayatlarının gizliliğini koruyacak bir istisnaya yer verilmemiş olduğunu anlamak zordur.

\footnotetext{
Tezcan, Erdem and Önok (n 7) 1259; Zafer (n 8) 1328; Döner (n 37) 89; Ayşe Nuhoğlu, 'Tip Hukukunda Zaruret Halinin Sınırları', Tip Ceza Hukukunun Güncel Sorunları (Türkiye Barolar Birliği 2008) 63.

133 Maral Törenli Çakıroğlu, 'Hekimin Borçlarından Özel Olarak Sır Saklama Borcu' (2010) 12 Dokuz Eylül Üniversitesi Hukuk Fakültesi Dergisi 159, 175.

134 Zafer (n 8) 1328.

135 Schönke and Schröder (n 12) 1457. Ancak bildirmemenin suç kabul edilmemesi için bu kişilerin suçu önlemek için çaba göstermeleri gerekmektedir. Heintschel-Heinegg (n 47) 998.
} 


\section{Tanıklıktan Çekinme Hakkı}

Ceza muhakemesinde çeşitli meslek gruplarına meslekleri sebebiyle öğrendikleri bilgiler açısından tanıklıktan çekinme hakkı tanınmıştır. Bu hak, meslek mensuplarının sır saklama yükümlülüklerinin muhakeme hukukunda somutlaşmış görünümünü teşkil etmektedir. 5271 sayılı CMK m 46/1(b)'de "Hekimler, diş hekimleri, eczacılar, ebeler ve bunların yardımcıları ve diğer bütün tıp meslek veya sanatları mensuplarının, bu sıfatları dolayısıyla hastaları ve bunların yakınları hakkında öğrendikleri bilgiler" açısından tanıklıktan çekinme haklarının bulunduğu ifade edilmiştir. Hatta bent uyarınca tanıklıktan çekinebilecek kişilerin bu konuda takdir yetkisinin bulunmadığı, hastalarının izni olmaksızın hiçbir şekilde tanıklık yapamayacakları, hastalarının rıza göstermesi halinde ise tanıklı yapmaya mecbur oldukları doktrinde ifade edilmiştiri ${ }^{136}$. Sonuç olarak sağlı meslek mensuplarının hastalarının rızasıyla sona erebilen bir tanıklıktan çekinme yükümlülüğünün bulunduğunu söylemek doğru olacaktır. Bu düzenlemeye karşın, sağlık meslek mensuplarının TCK m 280 uyarınca suçu bildirme yükümlülüğü mevcuttur. Tanıklıtan çekinme hakk1 ve suçu bildirme yükümlülüğünün birbiriyle karşıt sonuçlar yarattığı belirli durumların uygulamada görülmesi mümkündür. Örneğin, hastasının bir suç faili veya mağduru olduğunu öğrenen bir hekimin hem TCK m 280 uyarınca bu suçu bildirmesi gerekecek, hem de CMK m 46 uyarınca hastanın mağdur veya faili olduğu suçun yargılaması sırasında tanıklık yapmama hakkı bulunacaktır. Çelişkili gibi görünen bu durum hakkında madde metninin hazırlanması sirasında TBMM Adalet Komisyonu tutanaklarına yansıyan tartışma, doktrinde de süregelmiştir. Gerçekten, tutanaklarda görülebileceği üzere ${ }^{137}$ tanıklıktan çekinme hakkının ortadan kaldırıldığını ileri süren Soyaslan'a karşı Sözüer tanıklıktan çekinme hakkının suç oluşturmayan vakalar için geçerli olduğunu belirtmiş, TCK m 280'in kapsamına giren hallerde ise tanıklıktan çekinme hakkının olmadığını ifade etmiştir. Doktrinde bir görüş TCK m 280'in uygulanması halinde tanıklıktan çekinme hakkı arasında bir çelişki olduğunu belirtmektedir ${ }^{138}$. Diğer bir görüş uyarınca ise suçu bildirme yükümlülüğü ile tanıklıktan çekinme hakkı birbirinden bağımsız kurumlardır ve iki düzenleme arasında çatışma mevcut değildir ${ }^{139}$. Her iki kurumun birbirinden ayrı olduğunu belirten bu görüş sahipleri suçu bildirme yükümlülüğünün yargılama öncesi, tanıklıktan çekinmenin ise yargılama esnasında uygulanacağını, suçu bildiren sağlık meslek mensubunun daha sonra tanıklıktan çekinme hakkını kullanabileceğini belirtmektedir ${ }^{140}$. Son bir görüş ise CMK m 46/1(b) kapsamına giren hallerde suçu bildirme yükümlülüğünün mevcut olmayacağını ileri sürmektedir ${ }^{141}$.

\footnotetext{
136 Centel and Zafer (n 72) 275; Doğan Soyaslan, Ceza Muhakemesi Hukuku (6th edn, Yetkin Yayınları 2016) 447; Özbek and others (n 71) 701.

137 Niyazi Güney, Kenan Özdemir and Yusuf Balo, Türk Ceza Kanunu (Adil Yayınevi 2004) 795.

138 Kocasakal (n 21) 209; Tezcan, Erdem and Önok (n 7) 1259; Özbek and others (n 71) 700.

139 Bulut (n 7) 91.

140 Ünver, TCK'da Düzenlenen Adliyeye Karşı Suçlar - İftira, Suç Uydurma, Suç Üstlenme, Yalan Tanıklık ve Bilirkişilik, Infaz Kurumlarından Kaçma (n 13) 425; Erbaş (n 27) 169.

141 İplikçi (n 7) 101.
} 
Öncelikle belirtilmelidir ki; TCK m 280'in sağlık meslek mensuplarına suçu bildirim yükümlülüğünü açıkça yüklemiş olması sonucunda, muhakeme aşamasında kullanılacak bir hakkın suç bakımından hukuka uygunluk nedeni olduğunu ileri sürmek hatalı olacaktır ${ }^{142}$. Her ne kadar de lege ferenda arzu edilir bir sonuç olmasa da, benim de katıldığım görüşe göre, birçok halde tanıklıktan çekinme hakkının fiilen anlamsız hale gelmesine neden olacaksa da sağlık meslek mensupları kendi hastalarının veya hastaların yakınlarının faili olduğu suçlar bakımından da suçu bildirim yükümlülüğüne sahiptirler, ancak bu bildirimle bağlantılı olan yargılamada hastanın rızası olmaksızın tanıklık yapamayacaklardır. Böylece her iki düzenleme de uygulama alanı bulacaktır. Ancak doktrinde ileri sürülenin aksine, suçu bildirme yükümlülüğü ile tanıklıktan çekinme hakkının birbirinden tümüyle bağımsız düzenlemeler olduğunu kabul etmek de doğru değildir. Yukarıda da belirtilmiş olduğu üzere, bildirim yükümlülüğünün kapsamını, sağlık mesleği mensubunun suç konusu belirti ve buna ilişkin vardığı tıbbi kanaati içerir biçimde yorumlamak gerekmektedir. Böyle bir kabul sonucunda, örneğin hastasının faili olduğu bir suça ilişkin belirtiyle karşılaşan hekim, ilk olarak bu belirti ve belirti dolayısıyla suç teşkil edebilecek olgular hakkında edindiği bilgileri yetkili makamlara bildirecektir. Suçla ilgili yargılamanın başlatılmasının ardından ise, hekim hastasının rızası olmaksızın bu kanaati ve belirtiye tanıklığını mahkeme önünde dile getiremez hale gelmektedir. Yani hekim adeta yargılama öncesinde bilgisini iletmekle, yargılama sırasında ise iletmemekle yükümlüdür. Ancak her ne kadar hekim tanıklıktan çekinecek olsa da bunun anlamlı bir çekinme olduğunu söylemek mümkün değildir, zira halihazırda tanık ifadesine konu tüm bilgisini zaten yetkili makamlar ile paylaşmış bulunmaktadır. Belirtilmelidir ki, Adalet Komisyonu görüşmeleri esnasında dile getirilen hekimin tanıklıktan çekinme hakkının suç dışındaki konularda geçerli olduğuna dair düşünce de hatalı görünmektedir, çünkü tanıklık niteliği gereği hekimin suç konusunda beş duyusuyla öğrendiği bilgileri yargılamada mahkemeye sunmasından ibarettir ${ }^{143}$. Hukukumuzda sanığın kişiliği veya karakteri hakkında tanıklık bulunmadığına göre ${ }^{144}$ hekimin zaten suçtan bağımsız tıbbi bilgileri mahkeme ile paylaşması tanık ifadesi teşkil etmeyecektir.

Ayrıca, TCK m 280'deki düzenleme, suçu bildirme yükümlülüğünün ihlali konusundaki genel suç düzenlemesi olan TCK m 278'de yer alan tanıklıktan çekinme

\footnotetext{
${ }^{142}$ Aksi yönde bkz. Özgenç, 'Sağlık Mesleği Mensuplarının Suçu Bildirme Yükümlülüğünün Kapsam ve Sınırları' (n 90).

143 Centel and Zafer (n 72) 263; Birtek (n 73) 110

144 "Maddi vakıaya ilişkin olmayan hususlarda yapılan açıklamalar, doğrudan tanıklık kapsamında değerlendirilemez. (...) Ancak, tanıktan, sanığın kişiliğine ve ahlaki durumuna ilişkin bilgi alınabilmesi mümkün değildir. Bu türden tanıklık "kişilik tanıklı̆̆ı" olup, kişilik tanıklığının "subjektif bir kanaati içermesi sebebiyle" maddi vakıanın ortaya konulmasında bir ispat aracı olarak kullanılabilmesi mümkün değildir.” Bkz. Birtek (n 73) 154-155. Yazar CMK m 58/2 ve 59/1'de tanığın "tanıklık ettiği olay" ve "tanıklık yapacağı olay"dan söz etmesini kanunun açıkça kişilik tanıklığına izin vermemesi olarak yorumlamaktadır. Ancak yazarın da ifade ettiği üzere sanığın suçu işlediğinin sabit görülmesinin ardından takdiri indirim nedenlerinin uygulanıp uygulanmayacağı hususunun belirlenmesinde sanığın kişiliğine ilişkin konuların dinlenmesi mümkündür. Bu durumda bile tanık ifadesini somut olaya dayandırmak zorundadır. Bkz. Metin Feyzioğlu, Ceza Muhakemesi Hukukunda Tanıklık(US-A Yayıncılık 1996) 72-73.
} 
hakkına ilişkin istisna ile de uyumsuzdur. 5237 sayılı Türk Ceza Kanunu'nun hazırlanması aşamasında iki suç da tanıklıktan çekinme hakkını bir hukuka uygunluk nedeni olarak görmemekte idiyse de, AYM'nin 2011 yllında verdiği karar ${ }^{145}$ ile TCK m 278 iptal edilmiş ve kanun koyucu tarafindan tekrar düzenlenmiştir. Bu değişiklik ile maddeye eklenen dördüncü fikra, tanıklıktan çekinme hakkına sahip olanların TCK m 278 'den sorumlu tutulamayacağı kaydını içermektedir. Sağlı mesleği mensuplarının suçu bildirmemesi suçu için ise böyle bir düzenleme yapılmamıştır. Eğer tanıklıktan çekinme hakkına ilişkin bir istisnanın yokluğu TCK m 278'i Anayasa'ya aykırı hale getirmiş ise, bu istisnanın tanınmadığı TCK m 280'in de Anayasa m 38/5'e aykırı olduğu iddia edilebilir. Bu sorunun ve TCK m 278 ile m 280 arasındaki farklılığın derhal giderilmesi doğru olacaktır.

Sonuç olarak, mevcut düzenleme uyarınca TCK m 280 bakımından CMK m 46/1(b) bir hukuka uygunluk nedeni teşkil etmemektedir ve sağlık mesleği mensuplarının tanıklıktan çekinmeyi gerekçe göstererek suçu bildirmekten kaçınmaları ceza sorumluluklarını ortadan kaldırmayacaktır ${ }^{146}$. Ancak bu durum CMK m 46/1(b) düzenlemesinin amaca uygun bir biçimde uygulanmasını oldukça zor hale getirmektedir. Bu sebeple TCK m 280'in m 278 ile paralel biçimde, CMK m 46'ya uygun şekilde düzenlenmesi ve tanıklıktan çekinme hakkının mevcut olduğu hallerde suçun uygulanmayacağına ilişkin bir hukuka uygunluk nedeninin suç düzenlemesine eklenmesi doğru olacaktır ${ }^{147}$.

\section{D. İlgilinin Rıası}

TCK m 26/2 uyarınca "kişinin üzerinde mutlak surette tasarruf edebileceği bir hakkına ilişkin olmak üzere, açıkladığı rızası” ceza hukukumuzda bir hukuka uygunluk nedeni olarak düzenlenmiştir. Ancak TCK m 280 çerçevesinde ilgilinin rızasının uygulama alanı bulamayacağını belirtmek gerekir ${ }^{148}$. TCK m 26/2'nin uygulanması, ilgili suç düzenlemesiyle korunan hukuksal değerin belirli bir kişiye ait olduğu, yani suç mağdurunun belirli bir kişi olduğu hallerde mümkündür ${ }^{149}$. TCK m 280 ile korunan hukuksal değerler açıklandığı üzere suçların cezasız kalmaması, yargılamanın etkili biçimde yapılması ve bu şekilde cezaların konmasındaki amacın gerçekleştirilebilmesi ile kamu düzeninin sağlanmasıdır. Ayrıca suç TCK'nın dördüncü kısmının ikinci bölümünde adliyeye karşı işlenen bir suç olarak

\footnotetext{
145 AYM, E. 2010/52, K. 2011/113, 30.06.2011. Dikkat edilmesi gereken bir nokta, Anayasa'ya aykırılık itirazı ile AYM'nin iptal kararının dayanağının esasında tanıklıktan çekinme hakkına aykırılık değil, AY m 38'de düzenlenen susma hakkına aykırılık olduğudur. Kararın ilgili kısmı için bkz. dn. 131.

146 Tezcan, Erdem and Önok (n 7) 1259; Zafer (n 8) 1340.

147 Aynı yönde bkz. Tezcan, Erdem and Önok (n 7) 1260.

148 Öget (n 9) 79; Zafer (n 8) 1346; Tezcan, Erdem and Önok (n 7) 1260; Yağlidere (n 7) 72; Bulut (n 7) 91-92; Ünver, TCK'da Düzenlenen Adliyeye Karşı Suçlar - Iftira, Suç Uydurma, Suç Üstlenme, Yalan Tanıklık ve Bilirkişilik, İnfaz Kurumlarından Kaçma (n 13) 424; Kocasakal (n 21) 207.

149 Centel, Zafer and Çakmut (n 17) 330.
} 
düzenlenmiştir. Bu sebeple suçun mağduru belirli bir kişi değildir ve ilgilinin rızası TCK m 280 bakımından uygulanmayacaktır.

\section{Kusurluluğu Kaldıran Haller}

TCK m 280 kapsamında failin kusurunun bulunduğunun söylenemeyeceği bir durum, sağlık mesleği mensubunun tedavisi nedeniyle bildirimde gecikmiş olması, ancak bu durumun TCK m 25/2'de yer alan zorunluluk halini oluşturmasıdır.

Gerçekten sağlık mesleği mensubunun tedavide bulunma yükümlülüğü ile suçu bildirim yükümlülüğünün kimi zaman çakışması mümkündür. Hekimler ve ilgili diğer sağlık mesleği mensupları 2219 sayılı Hususi Hastaneler Kanunu ve Tıbbi Deontoloji Nizamnamesi uyarınca tıbbi müdahalede bulunma yükümlülüğüne sahiptirler. Kimi durumlarda hastaya yapılan müdahalenin acil olması ve uzun sürmesi nedeniyle sağlık mesleği mensubu karşılaştığı belirtiye ilişkin bildirimde bulunamayabilir veya gecikebilir. Tedavi sırasında suçun takibinin ciddi şekilde zorlaşmasının çok olası olmadığı, sağlık mesleği mensubunun tedavisinin hemen ardından bildirimde bulunmasının yeterli olacağı iddia edilebilir. Ancak örneğin bir hastanede yaralama suçunun işlenmesinin ardından bu suça tanık olan tek hekimin acil ilk yardımda bulunması ve mağduru ameliyata alması, bu sırada suç failinin kaçması ve izini kaybettirmesi gibi durumların gerçekleşmesi ihtimal dahilindedir. Bu durumda tedavi yükümlülüğünün üstün kabul edilmesi doğru olacaktır.

Sağlık mesleği mensubunun bir hastayı acilen tedavi etmesinin gerekmesi nedeniyle suçun bildirimini o an yapamaması durumunda, eğer bildirim için somut olayın koşullarında makul bir süre aşılmışsa zorunluluk halinin hükümlerinin uygulanması doktrinde önerilmiştir. Böyle bir durumda sağlık mesleği mensubu daha üstün bir hukuksal değer olan yaşam hakkı veya vücut bütünlüğünü korumak amacıyla suçu bildirme yükümlülüğüne uymaması söz konusudur. Üstün hukuksal değerin korunması için başka bir yol mevcut değil ise zorunluluk halinin koşulları gerçekleşecek ve sağlık mesleği mensubu kusurlu kabul edilmeyecektir ${ }^{150}$.

\section{Suçun Özel Görünüş Biçimleri}

\section{A. Teșebbüs}

TCK m 280'de düzenlenmiş olan sağlık mesleği mensuplarının suçu bildirmemesi suçu bildirim yükümlülüğünün yerine getirilmemesi veya geç yerine getirilmesi ile tamamlanmaktadır. Suç gerçek ihmali hareketle işlenebilen bir soyut tehlike suçudur. Doktrinde TCK m 280'in teşebbüse uygun olup olmadığı konusunda iki farklı görüş ortaya atılmıştır. Baskın görüş suçun ihmali hareketli suç niteliğinden hareketle

150 Öztürk and Erdem (n 62) 234; Zafer (n 8) 1347. 
teşebbüse uygun olmadığını dile getirmekte ${ }^{151}$, diğer görüş ise hareketin yapılmas1 için belli bir sürenin öngörüldüğü geç bildirimde bulunma hareketi bakımından teşebbüsün mümkün olabileceğini belirtmektedir ${ }^{152}$.

TCK m 280, bildirim yükümlülüğünün yerine getirilmemesi veya geç yerine getirilmesi şeklinde işlenir. Bildirim yükümlülüğünün doğmas1, yani sağl1k mesleği mensubunun görevi sırasında suç belirtisi ile karşılaşmasının ardından makul süre geçene kadar herhangi bir suç oluşmamaktadır, zira henüz geç bildirim söz konusu değildir. Bu sürenin geçmesinin ardından ise sağlık mesleği mensubu bildirimde bulunursa geç bildirimde bulunma suretiyle suçu işlemiş, hiç bildirimde bulunmaz ise bildirimde bulunmamak suretiyle suçu işlemiş olacaktır. Sağlık mesleği mensubunun dışında bir kişinin suça ilişkin yetkili makamlara bilgi vermesi ya da yetkili makamların herhangi bir şekilde suçtan haberdar olması da bildirim yükümlülüğünü kural olarak ortadan kaldırmayacaktır ${ }^{153}$. Hatta sağlık mesleği mensubunun suçu bildirmediğinin yetkili makamlarca öğrenilmesi ve bu şekilde yakalanması halinde bile artık bildirim yükümlülüğ̈̈nün ihmal edildiğinden ve suçun tamamlandığından bahsetmek gerekir. Bu nedenle sağlık mesleği mensubunun suç işlemeyi kastederek suçun icra hareketine başlaması ve suçu kendi elinde olmayan sebeplerle tamamlayamaması mümkün gözükmemektedir. Sonuç olarak kanımca sağlı mesleği mensubu bildirimin geç kabul edileceği ana dek TCK m 280'den sorumlu değildir, bu andan sonra ise suç tamamlandığ 1 için artık teşebbüsten söz edilemeyecektir. Bu nedenle TCK m 280 teşebbüse elverişli bulunmamaktadır ${ }^{154}$.

\section{B. İştirak}

Sağlık mesleği mensubunun suçu bildirmemesi suçu, faili bakımından özgü bir suçtur. TCK m 40/2 ${ }^{155}$ uyarınca yalnızca belirli sıfata sahip olan kişiler, yani sağlık mesleği mensupları suçun faili olabilirler. Buna karşılık diğer kişilerin suça azmettirme veya yardım etme biçiminde iştirak etmeleri mümkündür ${ }^{156}$. Özgü fail sıfatına sahip olmayan kişilerin bildirimde bulunmama kararına destekleri yardım etme veya azmettirme çerçevesinde değerlendirilecektir ${ }^{157}$.

\footnotetext{
151 Zafer (n 8) 1348; Çakmut (n 7) 1057; Yağlıdere (n 7) 75; Bulut (n 7) 92; İplikçi (n 7) 110; Kocasakal (n 21) 219; Koca and Üzülmez (n 10) 955; Meran (n 19) 1341.

152 Erbaş (n 27) 178; Ünver, TCK'da Düzenlenen Adliyeye Karşı Suçlar - Iftira, Suç Uydurma, Suç Üstlenme, Yalan Tanıklik ve Bilirkişilik, Infaz Kurumlarından Kaçma (n 13) 428.

153 Ünver, 'TCK'da Sağlık Personelinin Ceza Hukuku Sorumluluğuna Yol Açabilecek Hükümler' (n 13) 107. Bu durumun istisnası belirtildiği üzere sağlık mesleği mensubunun bildirimde bulunmamasının artık hukuken önemsiz hareket teşkil edeceği hallerdir. Bkz. III.C.2.b. Bildirmemek veya Bildirimde Gecikme Göstermek.

154 Aynı yönde bkz. Tezcan, Erdem and Önok (n 7) 1260; Çakmut (n 7) 1057.

1555237 sayılı TCK m 40/2: "Özgü suçlarda, ancak özel faillik niteliğini taşıyan kişi fail olabilir. Bu suçların işlenişine iştirak eden diğer kişiler ise azmettiren veya yardım eden olarak sorumlu tutulur"

156 Çakmut (n 7) 1058; İplikçi (n 7) 111; Ünver, TCK'da Düzenlenen Adliyeye Karşı Suçlar - Ifttira, Suç Uydurma, Suç Üstlenme, Yalan Tanıklık ve Bilirkişilik, İnfaz Kurumlarından Kaçma (n 13) 429.

157 Zafer (n 8) 1349; Erdoğan (n 107) 1110; Yağlıdere (n 7$) 76$.
} 
Birden fazla sağlık mesleği mensubunun görevleri sırasında aynı suça ilişkin belirtiyle karşılaşmaları ve birbirlerinden bağımsız olarak suçu bildirmemeleri halinde yan yana fail olacaklardır ${ }^{158}$. Yetkili makamlara bildirmemenin iştirak iradesi içerisinde gerçekleşmesi halinde ise her bir sağlık mesleği mensubu tipik fiili bizzat gerçekleştirdikleri için TCK m 280'in doğrudan faili olarak birlikte sorumlu olacaktır ${ }^{159}$.

\section{C. İçtima}

İçtima bakımından tartışmalı ilk nokta, TCK m 278-280 arasında düzenlenen suçu bildirmeme suçlarının aralarında nasıl bir içtima ilişkisi bulunduğudur. Buna göre çözülmesi gereken iki nokta vardır. Bunların ilki failinin bir sıfata sahip olması gerekmeyen TCK m 278 ile TCK m 280 arasındaki ilişkidir. İkinci olarak ise suçu bildirmeyen kişinin hem kamu görevlisi hem de sağlık mesleği mensubu sıfatını taşıması halinde TCK m 279'un mu, yoksa TCK m 280'in mi uygulanacağı sorununa değinilmelidir.

Öncelikle belirtilmelidir ki, TCK m 280 sağlık mesleği mensuplarının suçu bildirmemesini düzenleyen bir kanun hükmü olarak, TCK m 278'de yer alan faili özgü olmayan suçu bildirmeme suçuna göre özel hüküm teşkil etmektedir, zira TCK m 280, TCK m 278'in işlenmekte olan veya işlenmiş ama neticeleri engellenebilecek suçu bildirme yükümlülüğü biçiminde düzenlenmiş maddi unsuruna ek çeşitli unsurlar getirerek yalnızca sağlık meslek mensuplarını ilgilendiren ve kapsamı daha sınırlı bir suç öngörmüştür. Bu sebeple bir sağlık mesleği mensubunun görevi sırasında belirtisiyle karşılaştığı suçu bildirmemesi halinde TCK m 278'in unsurları oluşsa dahi bu suça ilişkin bir inceleme yapılmayacak, özel-genel hüküm kuralları çerçevesinde TCK m 280 uygulanacaktır ${ }^{160}$.

İkinci içtima sorunu, TCK m 280'in failinin hem kamu görevlisi hem de sağlik mesleği mensubu sıfatını taşıması halinde ortaya çıkmaktadır. Bu durumda kimi yazarların TCK m 279'un uygulanacağını, kimi yazarların ise TCK m 280'in uygulanacağını belirttikleri suçun failine ilişkin tartışmalar sırasında belirtilmişti ${ }^{161}$. Ayrıca, bu maddeler arasındaki ilişkinin doktrinde baskın olarak belirtilenin aksine özel-genel hüküm ilişkisi olmadığı da ifade edilmişti. Böyle bir durumda, TCK m 279 ve m 280 arasında kurulabilecek tek içtima ilişkisi, bir kişinin tek fiiliyle birden fazla farklı suçu işlemesini düzenleyen fikri içtima ilişkisidir ${ }^{162}$. TCK m 44'te yer alan düzenleme uyarınca fail yalnızca en ağır cezayı gerektiren suçtan dolayı cezalandırılır. Buna göre, bir kamu kurum veya kuruluşunda kamu görevlisi sıfatıyla

\footnotetext{
Tezcan, Erdem and Önok (n 7) 1261; Kocasakal (n 21) 219.

159 Erdoğan (n 107) 1110.

160 Erbaş (n 27) 180; Döner (n 37) 91.

161 Bkz. III.B. Fail.

162 Aynı yönde bkz. Zafer (n 8) 1336; Tezcan, Erdem and Önok (n 7) 1261.
} 
çalışan sağlık mesleği mensubu, görevi sırasında kamu adına soruşturmayı gerektiren bir suçun işlendiğini gösteren bir belirti ile karşılaşması ve bu suçu yetkili makamlara bildirmemesi halinde hem TCK m 279 hem de TCK m 280'deki suçu işlemiş olacaktır. TCK m 279'da düzenlenen suçun cezası sağlık mesleği mensubunun suçu bildirmemesi suçunu düzenleyen TCK m 280'e göre daha ağır olduğu için, fikri içtima kuralı uyarınca böylesi durumlarda TCK m 279 uygulanmalıdır. Ancak kamu görevlisi sıfatını taşıyan sağlık mesleği mensubunun belirtisiyle karşılaştı̆̆ı suçun re'sen kovuşturulacak bir suç olmaması halinde TCK m 279'un unsurları oluşmayacak, böylesi bir durumda TCK m 280 uygulanacaktır.

Suçu bildirmeme suçları arasındaki içtima sorununun çözülmesinin ardından, içtima kurumuna ilişkin ortaya çıkabilecek diğer hallerin üzerinde durulmalıdır.

Kamu görevlisi bir sağlık mesleği mensubunun öğrendiği bir suçu bildirmemesi durumunda unsurlarının oluşması halinde TCK m 257'de düzenlenen görevi kötüye kullanma suçu ve TCK m 280'in tek fiille işlenmesi söz konusu olabilecektir. Böyle bir halde, TCK m 257'nin oluşması için 'kanunda ayrıca suç olarak tanımlanan haller dışında" bir durumun mevcut olması açıkça arandığı için TCK m 257'nin tali bir hüküm olduğunu belirtmek gerekir ${ }^{163}$. Bu sebeple hem TCK m 280 hem de TCK m 257 'nin unsurları olayda gerçekleştiyse de uygulanacak hüküm yalnızca asli hüküm olan TCK m 280'dir ${ }^{164}$.

Uygulamada karş1laşılabilecek diğer örnekler, sağlık mesleği mensubunun belirli bir meblağ karşılığında belirtisiyle karşılaştığı suçu yetkili makamlara bildirmemeyi kabul etmesi veya sağl1k mesleği mensubunun suçu yetkili makamlara bildirmemek amacıyla hazırladığı teşhis raporunu gerçeğe aykırı biçimde düzenlemesidir. İlk durumda, sağlık mesleğinin kamu görevlisi olması halinde TCK m 252'de yer alan rüşvet suçu işlenmiştir. $\mathrm{Bu}$ durumda rüşvet fiili ve yetkili makamlara bildirmeme birbirinden ayrı fiiller olduğu için aralarında fikri içtima ilişkisi kurulmayacak, sağlık mesleği mensubu hem TCK m 252/2 uyarınca, hem de TCK m 280 uyarınca cezalandırılacaktır ${ }^{165}$. Sağlık mesleği mensubunun gerçeğe aykırı belge düzenlemesi halinde ise TCK m 210/2 hükmü uygulanmalıdır ${ }^{166}$. Bu kurala göre, gerçeğe aykırı belge düzenleyen sağlık mesleği mensubu üç aydan bir yıla kadar hapis cezasıyla cezalandırılacaktır. Bildirimin yapılmaması amacıyla belgenin gerçeğe aykırı düzenlenmesi halinde TCK m 210/2 ve m 280 tek fiil ile işlenmiş sayılmalıdır ${ }^{167}$. Böyle

\footnotetext{
163 İzzet Özgenç, Irtikap, Rüşvet ve Görevi Kötüye Kullanma Suçları (Seçkin Yayıncılık 2013) 154.

164 Erbaş (n 27) 185.

165 İplikçi (n 7) 112.

166 Suça ilişkin bilgi için bkz. Ahmet Gökcen, Belgede Sahtecilik Suçları (5237 s.lı TCK. m 204-212) (Turhan Kitabevi 2006) 201-215; Devrim Güngör, Resmi Belgede Sahtecilik Suçu (Yetkin Yayınları 2010).

167 Krş. Ünver, TCK'da Düzenlenen Adliyeye Karşı Suçlar - Iftira, Suç Uydurma, Suç Üstlenme, Yalan Tanıklık ve Bilirkişilik, Infaz Kurumlarından Kaçma (n 13) 429. Yazar böyle bir durumda doğrudan TCK m 204/2'nin uygulanacağını belirtmişse de TCK m 210/2 düzenlemesi karşısında resmi belgede sahtecilik suçunun uygulanabilmesi için "düzenlenen belgenin kişiye haksız bir menfaat sağlaması ya da kamunun veya kişilerin zararına bir sonuç doğurucu nitelik taşıması" gerektiğini
} 
bir durumda sahte resmi belgenin bir başka suçun işlenmesi sırasında kullanıldığının kabulü gerekecek ve her iki suçtan dolayı TCK m 212 hükmü uyarınca ayrı ayrı cezaya hükmolunacaktır.

Son olarak, sağlık mesleği mensubunun görevi sırasında aynı suça ilişkin birden fazla belirtiyle karşılaşması durumunda tek bir bildirim yükümlülüğünün ihlali ve dolayısıyla tek bir TCK m 280'in oluşacağını belirtmek gerekir ${ }^{168}$. Ancak sağlık mesleği mensubunun görevi sırasında karşılaştığı her ayrı suça ilişkin belirti, bağımsız bildirim yükümlülüklerini doğuracak ve bunların ihlali bağımsız suçu bildirmeme suçlarından sorumluluğu gerektirecektir. Zincirleme suç hükümlerinin böyle bir durumda uygulanması uygulamada karşılaşılması pek olası görülemeyecek biçimde sağl1k mesleği mensubunun önceden karşısına çıkacak suçları bildirmeme kararı almış olmasıdır ${ }^{169}$. Bu halde bile birçok durumda failin somut bir suç işleme kararı ve dolayısıyla zincirleme suçun varlığından bahsedilemeyecek, firsatlardan yararlanarak suçu işlediğini söylemek daha doğru olacaktır.

\section{Yaptırım ve Kovuşturma}

TCK m 280 uyarınca görevi sırasında bir suç işlendiğini gösteren belirtiyle karşılaşan sağlık mesleği mensubu, bunu yetkili makamlara bildirmez veya geç bildirimde bulunursa bir yıla kadar hapis cezasıyla cezalandırılacaktır.

Hapis cezasının üst sınırı bir yıl olduğu için, hükmedilecek ceza kısa süreli hapis cezasıdır ve TCK m 50 uyarınca seçenek yaptırımlara çevrilmesi mümkündür. Ayrıca hükmedilebilecek somut ceza iki yılın altında olacağı için, TCK m 280 dolayısıyla verilecek hükmün CMK m 231 uyarınca açıklanması geriye bırakılabilecek veya TCK m 51 uyarınca cezanın ertelenmesi yoluna gidilebilecektir.

Hapis cezasının verilmesi halinde hüküm giyen sağlık mesleği mensubu ayrıca cezasının infazı süresince TCK m 53 uyarınca hükmün kanuni sonucu olarak belirli hakları kullanmaktan yoksun bırakılacaktır.

TCK m 280'de düzenlenen suçun soruşturulması ve kovuşturulması herhangi bir muhakeme şartına tabii değildir, soruşturma ve kovuşturma yetkili makamlar tarafindan re'sen yapılacaktır.

TCK m 280 bakımından önemli bir konu, 17 Ekim 2019 tarihinde TBMM tarafindan kabul edilen 7188 sayılı Kanun ${ }^{170}$ ile Ceza Muhakemesi Kanunu'nda yapılan değişikliklerdir.

ifade etmek gerekir. Kamu görevlisi olan ve resmi belge düzenlemeye ehil sağlık mesleği mensuplarının düzenlediği belgeler için ise pek tabii TCK m 204 uygulanabilir.

168 Kocasakal (n 21) 220; Zafer (n 8) 1348.

169 Böyle bir durumda TCK m 43’ün uygulanacağına dair bkz. İplikçi (n 7) 112.

1707188 sayılı ve 17.10.2019 tarihli Ceza Muhakemesi Kanunu ve Bazı Kanunlarda Değişiklik Yapılmasına Dair Kanun. Kanun 30928 sayılı ve 24.10.2019 tarihli Resmi Gazete'de yayımlanarak yürürlüğe girmiştir. 
Değişikliğin ardından CMK m 171 uyarınca Cumhuriyet savcısının kamu davasının açılmasının ertelenmesi kararı verme yetkisinin genişletildiği ifade edilmelidir. Değişiklik Cumhuriyet savcısına üst sınırı üç yıl veya daha az olan suçlarda, suçun takibinin şikayet koşuluna bağlı olup olmasına bakılmaksızın kamu davasının açılmasının 5 yıl ertelenmesi kararı verme yetkisi tanınmaktadı1 ${ }^{171}$. Takibi şikayete bağlı olmayan ve öngördüğü hapis cezasının üst sınırı 1 yıl olan TCK m 280 uyarınca yapılan soruşturmalarda da, savcı suçun işlendiğine dair yeterli şüpheye ulaşsa da bu yetkisini kullanabilecek ve kamu davasının açılmasını erteleyebilecektir.

Ayrıca belirtilmelidir ki, 7188 sayılı Kanun ile CMK m 245'te yapılan değişiklik aracılığıyla Türk ceza adaleti sistemine giren basit yargılama usulü, TCK m 280 için de uygulanabilmektedir. Bu usul yalnızca adli para cezası ve/veya üst sınırı 2 yıl veya daha az süreli hapis cezasını gerektiren suçlar bakımından mümkündür. TCK m 280'de yer alan sağlik meslek mensubunun suçu bildirmemesi suçu da bu kapsamda bulunmaktadır. Suçun kovuşturulmasının duruşma açılmaksızın dosya üzerinden yapılmasını öngören bu usulde kovuşturmayı yapacak Asliye Ceza Mahkemesi iddianamenin kabulünün ardından yargılamanın taraflarına 15 günlük yazılı beyan süresi tanımakta ve beyanlar üzerine incelemesini duruşmasız ve Cumhuriyet savcısının görüşünü almaksızın hükmünü kuracak, ancak hükmedilen cezada dörtte bir oranında indirim yapacaktır. Bu cezanın olağan yargılama usulüne göre verilen hükümler gibi hükmün açıklanmasının geriye bırakılması, cezanın ertelenmesi veya seçenek yaptırımlara çevrilmesi uygulamalarına tabi tutulması da mümkün olacaktır. Ancak dikkat edilmelidir ki basit yargılama usulü sonucunda verilen hükme itiraz edilmesi halinde kovuşturma duruşmalı olarak baştan yapılacaktır. Ayrıca basit yargılama usulünün sadece 1 Ocak 2020 tarihinden sonra kovuşturma aşamasına geçecek yargılamalarda uygulanabileceği unutulmamalıdır.

\section{Sonuç ve Öneriler}

Suçların aydınlatılması ve işlenen suçlar üzerine etkili bir soruşturma ve kovuşturmanın yapılması, devletin bireylere karşı temel yükümlülüklerinden ve ceza adaleti sisteminin ana amaçlarından biridir. Bu çalışmada, bu amacın gerçekleştirilebilmesi için bireylerin katkısını bir yükümlülük haline getiren, bu yükümlülüğün ihlalini hapis cezasına tabi tutan 5237 sayılı TCK m 280'de yer alan "Sağlık mesleği mensuplarının suçu bildirmemesi suçu" üzerinde durulmuştur.

TCK m 280 dil olarak basit ve kısa bir düzenleme olsa da pek çok unsuru üzerinde yoğun doktriner tartışmalar mevcuttur. Özellikle suçun benzer suçlar olan TCK m 278 ve $\mathrm{m} 279$ ile ilişkisi, suçun özgü faili olan sağlık mesleği mensubu kavramının tanımı, failin sahip olduğu bildirim yükümlülüğünün doğmasının şartları ve bildirimin yerine

$\overline{171}$ Değişiklik öncesi savcı bu kararı ancak üst sınırı bir yıl veya daha az olan ve soruşturulması ve kovuşturulması şikayete bağlı suçlar bakımından verebilmekteydi. 
getirilmesi konuları üzerine çok çeşitli görüşler ortaya atılmıştır. Tartışmalar 1şığında aşağıdaki noktalara tekrar dikkat çekilmesi uygun olacaktır.

Öncelikle, TCK m 280'in failinin sağlık mesleği mensubu sıfatını taşıması gerektiği hükümde açıkça belirtilmiş ve bu kavram hükmün ikinci fikrasında açıklığa kavuşturulmaya çalışılmışsa da, bu çabanın yeterli olduğunu söylemek mümkün değildir. Aynı zamanda kamu görevlisi olan sağlık mesleği mensuplarının bu suç kapsamında fail olup olamayacakları ve hatta sağlık mesleği mensubu kavramının veteriner hekimler gibi kimi meslek gruplarını kapsayıp kapsamadığı belirsizdir. Kanımca sağlık mesleği mensubu 1219 ve 657 sayılı Kanunlar uyarınca, hekimler, diş hekimleri, hemşireler, hastabakıcılar, eczacılar, veterinerler ve sağlık hizmeti verdiği mevzuatta ifade edilen diğer kişiler olarak kabul edilmeli ve TCK m 280 hem kamu görevlileri hem de özel kurum ve kuruluşlarda veya serbest olarak çalışan kişilere uygulanabilmeliyse de, kapsam üzerinde öğretide uzlaşı sağlanamamıştır. Bu sorunun temel sebebi, fail sıfatının tanımının yalnızca örnekleyici sayımla yapılmış olmasıdır. Halbuki, örnekleyici sayım bir tanımlama yöntemi değildir. Suçta ve cezada kanunilik ilkesinin alt unsurlarından biri olan belirlilik ilkesinin gereklerine uygun olarak TCK m 280'in faili olan sağlık mesleği mensubunun kim olduğunun kanunla açık ve kesin bir biçimde ortaya konması doğru olacaktır. Böylesine bir tanımlama suçun kamu görevlisi sağlık mesleği mensuplarına uygulanıp uygulanmayacağı tartışmasına da son verecektir.

İkinci olarak, kanun koyucunun birbirine yakın hükümler olan TCK m 278, m 279 ve m 280'de suçun fiil unsurunda neden farklı düzenleme yöntemlerine gittiğini anlamak zordur. TCK m 278'de yalnızca işlenmekte olan bir suçu yetkili makamlara bildirmekten söz edilmişken, TCK m 279'da suçun işlendiğini öğrenmek, TCK m 280'de ise suçun işlendiği yönünde belirti ile karşılaşmak bildirim yükümlülüğünün doğmasına sebep olmaktadır. Bu kapsamda TCK m 280'de yer alan suçun oluşması için belirtiyle karşılaşılmasının gerekmesi, belirti kavramının da anlamının önem kazanması sonucunu doğurmaktadır. Doktrinde kavram her ne kadar ceza muhakemesi öğretisinin sistematiğine uygun bir şekilde yorumlanmışsa da, bu yorumun kanuni dayanağı olmadığı gibi, kanun koyucunun belirti, delili, iz ve emare kelimelerini de özensizce kullandığı dikkat çekmektedir. Bu sebeple kanımca suçun işlendiğini gösteren herhangi bir emare ile karşılaşılması, bu sözlü bir ifade, bir belge veya maddi iz de olsa, bildirim yükümlülüğünün doğması için yeterlidir. Yine de, suç tanımında yer alan belirti kavramı yerine TCK m 278 ve m 279 ile daha uyumlu bir düzenlemeye yer verilmesi anlam karmaşasını çözebilecektir.

Öğretide ortaya çıkan bir diğger tartışma, TCK m 280'in olası kastla işlenip işlenemeyeceğine dairdir. Bu konuda çalışmada aktarılan görüşün suçun olası kastla işlenebileceği yönünde olduğunu ifade etmek gerekir. Hatta belirtmek gerekir ki; 
suçun olas1 kastla işlenmesi, doğrudan kastla işlenmesinden daha muhtemeldir. Gerçekten, doğrudan kast yalnızca sağlık mesleği mensubunun karşılaştı̆̆ olgunun suça işaret eden bir belirti olduğunu ve bunu bildirme yükümlülüğünün bulunduğunu bildiği halde oluşmuş kabul edilmelidir. Bunun dışındaki ihtimallerde, yani sağlık mesleği mensubunun karşılaştığı olgunun suç belirtisi olduğundan emin olmadığı, bu konuda yalnızca bir öngörüsünün bulunduğu durumlarda ise olası kasttan bahsetmek daha doğru olacaktır.

Bir diğer sorun, suçta sağl1k mesleği mensubunun önemli yükümlülüklerinden olan tedavi yükümlülüğü ve sır saklama yükümlülügü̈ne aykırı yorumlanabilecek bir düzenleme yoluna gidilmiş olmasıdır. TCK m 280 ile hekimin sır saklama yükümlülüğüne bir istisna getirilmiş olduğu genel kabul gören bir yargı olsa da, bu yükümlülüğün bir uzantısı olan tanıklıktan çekinme hakkına dair herhangi bir kaydın hükme eklenmemesi, bildirim yükümlülüğü ve çekinme hakk1 arasındaki ilişki konusunda görüş ayrllıklarına sebep olmuştur. Özellikle TCK m 278'e tanıklıktan çekinme hakkının mevcut olduğu hallerde suçun uygulanmayacağına dair bir istisna getirilmiş olmasına karşın aynı düzenlemenin TCK m 280'de yapılmaması düzeltilmesi gereken bir sorundur. Aynı şekilde, 765 sayılı mülga Türk Ceza Kanunu'nun ilgili düzenlemesinde sağl1k mesleği mensubunun tedaviye öncelik vereceğine dair açık bir kural varken aynı kuralın TCK m 280'e alınmaması olumsuz bir gelişmedir.

Son olarak, TCK m 280 ile kanun koyucunun sağlık mesleği mensubunun görevi sırasında karşılaştığ1 her suçu bildirmekle yükümlü tutması ve bu şekilde sağlık mesleği mensuplarını adeta hafiye haline getirmesi doğru olmamıştır. Özellikle cezası hafif suçlar ve şikayete bağlı suçlarda da bu yükümlülüğün istisnasız bir biçimde yer alması sağlık hakkını olumsuz etkileyebilecek sonuçlara gebedir. Ayrıca, suç tanımının bu denli geniş ve kapsayıcı olması, uygulama ile mevzuat arasında da farklılıklara yol açmaktadır. Belirtilmiş olduğu üzere uygulamada adli vaka olarak tanımlanan ve bildirim konusu yapılan suçlar genellikle kişilere karşı işlenen ve tedavi edilen kişinin mağduru olduğu suçlardır. Buna karşılık TCK m 280, yöneldiği kişi ve hukuki değer konusunda ayrım gözetmeksizin her suçun bildirilmesini emretmektedir. Uygulamada bu yükümlülüğe ne denli uyulduğu belirsizdir. Fiiliyat ve mevzuat arasındaki bu uyuşmazlığın hükmün uygulanabilirliği açısından çözülmesi elzemdir.

Finansal Destek: Yazar bu çalışma için finansal destek almamıştır. 


\section{Bibliyografya/Bibliography}

Akbulut B, Ceza Hukuku Genel Hükümler (5th edn, Adalet Yayınevi 2018)

Arslan Ç and Azizağaoğlu B, Yeni Türk Ceza Kanunu Şerhi (Asil Yayın Dağıtım 2004)

Artuk ME and Gökcen A, Ceza Hukuku Genel Hükümler (11th edn, Adalet Yayınevi 2017)

Birtek F, Ceza Muhakemesinde Delil ve Ispat (Adalet Yayınevi 2015)

Bulut P, 'Sağlık Mesleği Mensuplarının Suçu Bildirmemesi’, Sağlık Hukuku Makaleleri (İstanbul Barosu Yayınları 2012)

Çakmut ÖY, 'Sağlık Mesleği Mensuplarının Suçu Bildirmemesi Suçu (TCK m 280)' (2006) 12 Marmara Üniversitesi Hukuk Fakültesi Hukuk Araştırmaları Dergisi 1051

Centel N and Zafer H, Ceza Muhakemesi Hukuku (15th edn, Beta Yayınevi 2018)

Centel N, Zafer H and Çakmut Ö, Kişilere Karşı Işslenen Suçlar Cilt: I (4th edn, Beta Yayınevi 2017)

Centel N, Zafer H and Çakmut Ö, Türk Ceza Hukukuna Giriş (10th edn, Beta Yayınevi 2017)

Demirbaş T, Ceza Hukuku Genel Hükümler (13th edn, Seçkin Yayıncılık 2018)

Döner İ, 'Suçu Bildirmeme Suçu (TCK m 278)' (2005) 9 Ankara Üniversitesi Hukuk Fakültesi Dergisi 63

Erbaş R, Türk Hukukunda ve Karşılaştırmalı Hukukta Sağlık Mesleği Mensuplarının Suçu Bildirme Yükümlülüğ̈̈ (On İki Levha Yayıncılık 2015)

Erdem MR, ‘Suçu Bildirmeme Suçu (TCK m 278)’ [2009] Türkiye Barolar Birliği Dergisi 105

Erdoğan Y, 'Sağlık Mesleği Mensuplarının Suçu Bildirmeme Suçu’ [2009] Legal Hukuk Dergisi 1103

Feyzioğlu M, Ceza Muhakemesi Hukukunda Tanıklı (US-A Yayıncılık 1996)

Fischer T, Beck'sche Kurz Kommentare - Strafgesetzbuch Und Nebengesetzen (57th edn, Verlag $\mathrm{CH}$ Beck 2009)

Gökcen A, Belgede Sahtecilik Suçları (5237 s.Lı TCK. m 204-212) (Turhan Kitabevi 2006)

Gökpınar M, 'Ceza Sorumluluğunun Temeli: “Kast”' [2008] Türkiye Barolar Birliği Dergisi 198

Gültekin Ö, ‘Sağlık Mesleği Mensuplarının Suçu Bildirmemesi’ (2016) 11 Terazi Hukuk Dergisi 103

Güney N, Özdemir K and Balo Y, Türk Ceza Капипu (Adil Yayınevi 2004)

Güngör D, Resmi Belgede Sahtecilik Suçu (Yetkin Yayınları 2010)

Hafızoğulları Z and Özen M, Türk Ceza Hukuku Özel Hükümler Kişilere Karşı Suçlar (US-A Yayınc1lı 2010)

Hakeri H, ‘Ceza Hukukunda Önemsiz Hareketler' [2007] Türkiye Barolar Birliği Dergisi 55

Hakeri H, Tip Hukuku (16th edn, Seçkin Yayınc1lık 2019)

Heintschel-Heinegg B, Strafgesetzbuch Kommentar (Verlag CH Beck 2010)

İçel K, Suçların İçtimaı (Sermet Matbaası 1972)

İçel K, 'Görünüşte Birleşme (İçtima) İlkeleri ve Yeni Türk Ceza Kanunu' (2008) 7 İstanbul Ticaret Üniversitesi Sosyal Bilimler Dergisi 35

İplikçi HE, ‘Türk Ceza Hukukunda Suçu Bildirmeme Suçları' (Ankara Üniversitesi 2010)

Janis MW, Kay RS and Bradley AW, European Human Rights Law (Oxford University Press 2008) Joecks W, Studienkommentar Strafgesetzbuch (9th edn, Verlag CH Beck 2010) 
Karabulut F, Karapazarlığlu E and Tosun H, 'Ceza Muhakemesinde Delil Kavramı ve Kovuşturma Sürecinde Hakimlerin Delil Algısı’ [2015] Türkiye Barolar Birliği Dergisi 385

Karan U, 'Yaşam Hakkı' in Sibel İnceoğlu (ed), İnsan Hakları Avrupa Sözleşmesi ve Anayasa (Avrupa Konseyi 2013)

Keten A and others, 'Acil Serviste Düzenlenen Adli Raporların Türk Ceza Kanunu Kapsamında Değerlendirilmesi’ (2011) 5 Turkish Medical Journal 94

Koca M and Üzülmez İ, Türk Ceza Hukuku Genel Hükümler (10th edn, Seçkin Yayınc1lık 2017)

Koca M and Üzülmez İ, Türk Ceza Hukuku Özel Hükümler (4th edn, Seçkin Yayıncılık 2017)

Kocasakal Ü, Suçu Bildirmeme Suçları (1st edn, Vedat Kitapçılık 2017)

Kolcu S, 'TCK'da Suçu Bildirmeme Suçu’ (İstanbul Kültür Üniversitesi 2014)

Lackner K and Kühl K, Strafgesetzbuch Kommentar (26th edn, Verlag CH Beck 2007)

Meran N, Açıklamalı-İçtihatlı Yeni Türk Ceza Kanunu (2nd edn, Seçkin Yayıncılık 2007)

Nuhoğlu A, 'Tıp Hukukunda Zaruret Halinin Sınırları', Tıp Ceza Hukukunun Güncel Sorunları (Türkiye Barolar Birliği 2008)

Öget M, 'Sağlık Mesleği Mensuplarının Suçu Bildirmemesi (TCK 280)' [2015] Leges İzmir Üniversitesi Sağlık Hukuku Dergisi 53

Özbek VÖ and others, Ceza Muhakemesi Hukuku (8th edn, Seçkin Yayınc1lık 2016)

Özbek VÖ and others, Türk Ceza Hukuku Genel Hükümler (8th edn, Seçkin Yayıncılık 2017)

Özgenç İ, ‘Kast-Taksir Kombinasyonları' (1998) 6 Selçuk Üniversitesi Hukuk Fakültesi Dergisi 345

Özgenç İ, 'Sağlık Mesleği Mensuplarının Suçu Bildirme Yükümlülüğünün Kapsam ve Sınırları' (Sağllk Düşüncesi ve Tip Kültürü Platformu, 2008) <http://www.sdplatform.com/Dergi/169/ Saglik-meslegi-mensuplarinin-sucu-bildirme-yukumlulugunun-kapsam-ve-sinirlari.aspx $>$ accessed 24 September 2019

Özgenç İ, İrtikap, Rüşvet ve Görevi Kötüye Kullanma Suçları (Seçkin Yayınc1lık 2013)

Özgenç İ, Türk Ceza Hukuku Genel Hükümler (14th edn, Seçkin Yayınc1lık 2018)

Özgüç LE, 'Bireysel Başvuru İçtihatlarında Yaşam Hakkının Usuli Boyutu: Etkili Soruşturma Yükümlülüğ̈̈’ (2016) 10 Güncel Hukuk 32

Öztürk B and others, Nazari ve Uygulamalı Ceza Muhakemesi Hukuku (11th edn, Seçkin Yayıncılık 2017)

Öztürk B and Erdem MR, Uygulamalı Ceza Hukuku ve Güvenlik Tedbirleri Hukuku (16th edn, Seçkin Yayıncılık 2016)

Schönke A and Schröder H, Strafgesetzbuch Kommentar (28th edn, Verlag CH Beck 2010)

Şenol C, Avrupa Insan Hakları Mahkemesi Kararlarında Etkin Soruşturma Yükümlülüğü (CMK m 172/3) (On İki Levha Yayıncılık 2013)

Soyaslan D, Ceza Muhakemesi Hukuku (6th edn, Yetkin Yayınları 2016)

Tezcan D and others, Insan Hakları El Kitabı (8th edn, Seçkin Yayıncılık 2019)

Tezcan D, Erdem MR and Önok RM, Teorik ve Pratik Ceza Özel Hukuku (16th edn, Seçkin Yayınc1lık 2018)

Törenli Çakıroğlu M, 'Hekimin Borçlarından Özel Olarak Sır Saklama Borcu' (2010) 12 Dokuz Eylül Üniversitesi Hukuk Fakültesi Dergisi 159

Toroslu N, Ceza Hukuku Özel Kısım (5th edn, Savaş Yayınevi 2010) 
Toroslu N and Toroslu H, Ceza Hukuku Genel Kısım (21st edn, Savaş Yayınevi 2015)

Ünver Y, 'Hekimin Cezai Sorumluluğu', Roche Sağglk Hukuku Günleri (Roche Müstehzarları Sanayi 2007)

Ünver Y, 'TCK'da Sağlık Personelinin Ceza Hukuku Sorumluluğuna Yol Açabilecek Hükümler', Uluslararası II. Sağlık Hukuku Sempozyumu (On İki Levha Yayıncılık 2011)

Ünver Y, TCK'da Düzenlenen Adliyeye Karşı Suçlar - Iftira, Suç Uydurma, Suç Üstlenme, Yalan Tanıklık ve Bilirkişilik, Infaz Kurumlarından Kaçma (5th edn, Seçkin Yayıncılık 2019)

Üzülmez İ, 'Sağlık Mesleği Mensuplarının Suçu Bildirmemesi Suçu', Tıp Ceza Hukukunun Güncel Sorunları (Türkiye Barolar Birliği 2008)

Yağlıdere UE, 'Sağlık Mesleği Mensuplarının Suçu Bildirmemesi Suçu' (2018) 6 Kadir Has Üniversitesi Hukuk Fakültesi Dergisi 59

Yaşar O, Gökcan HT and Artuç M, Yorumlu-Uygulamalı Türk Ceza Kanunu Cilt VI (Adalet Yayınevi 2010)

Yenisey F and Nuhoğlu A, Ceza Muhakemesi Hukuku (6th edn, Seçkin Yayıncılık 2018)

Zafer H, 'Sağlık Mesleği Mensuplarının Suçu Bildirmemesi Suçu (TCK m 280)' (2013) 71 İstanbul Üniversitesi Hukuk Fakültesi Mecmuası 1327 